\title{
Tectonic controls on surface erosion rates in the Longmen Shan, Eastern Tibet
}

Wei Wang ${ }^{1 *}$, Vincent Godard ${ }^{2,3}$, Jing Liu-Zeng ${ }^{1,4 *}$, Jinyu Zhang ${ }^{1}$, Zhigang Li $^{5}$, Sheng Xu ${ }^{4}$, Wenqian Yao $^{4}$, Zhaode Yuan ${ }^{1}$, Georges Aumaître ${ }^{2}$, Didier L. Bourlès², Karim Keddadouche²

${ }^{1}$ State Key Laboratory of Earthquake Dynamics, Institute of Geology, China Earthquake Administration, Beijing, China

${ }^{2}$ Aix Marseille Univ, CNRS, IRD, INRAE, Coll France, CEREGE, 13545 Aix-en-Provence, France

${ }^{3}$ Institut Universitaire de France (IUF), Paris, France

${ }^{4}$ Institute of Surface-Earth System Science, Tianjin University, Tianjin, China

${ }^{5}$ Guangdong Provincial Key Lab of Geodynamics and Geohazards, School of Earth Sciences and

Engineering, Sun Yat-sen University, Guangzhou, China

*Corresponding author: Wei Wang (wangwei41178@yahoo.com); Jing Liu-Zeng

(earofwood@yahoo.com)

\section{Key Points:}

- ${ }^{10}$ Be-derived catchment-wide denudation rates are positively correlated with topographic indices in the southern Longmen Shan.

- Erosion rates are consistent over short- and long-term timescales across the Longmen Shan, suggesting an exhumational steady state.

- Rock uplift pattern and topographic evolution across the Longmen Shan have been largely controlled by upper crustal shortening and fault geometry.

Manuscript published in Tectonic. Full citation: Wang, W., Godard, V., Liu-Zeng, J., Zhang, J., Li, Z., Xu, S., Yao, W., Yuan, Z., Aumaître, G., Bourlès, D. L., and Keddadouche, K., 2021, Tectonic Controls on Surface Erosion Rates in the Longmen Shan, Eastern Tibet: Tectonics, v. 40, no. 3, p. e2020TC006445. 


\section{Abstract}

The Longmen Shan range, located on the eastern margin of the Tibetan Plateau, is characterized by steep topography and a shortening rate of $<3 \mathrm{~mm} / \mathrm{yr}$. This peculiar configuration is a source of controversy and questions about the topographic evolution and dynamics of this orogenic plateau margin. Investigating the variations in surface denudation over different spatial and temporal scales is important for a better understanding of topographic evolution, but there is still a lack of erosion-rate data averaged over millennial timescales along the frontal range of the Longmen Shan, especially in its southern part. We present 25 new catchment-wide denudation rates derived from ${ }^{10} \mathrm{Be}$ concentrations in river sediments across the southern Longmen Shan. Our results show that average denudation rates increase from $<0.15 \mathrm{~mm} / \mathrm{yr}$ near Ya'an, located in the Sichuan Basin, northwestward to $>0.50 \mathrm{~mm} / \mathrm{yr}$ inside the southern Longmen Shan. The denudation rates correlate with slope gradient, relief, channel steepness, and specific stream power, but exhibit a fair degree of scattering at high values. In combination with previous ${ }^{10} \mathrm{Be}$ and low-temperature thermochronology analyses, we found the denudation rates over kyr- to Myr-timescales to be roughly consistent across the southern Longmen Shan, suggesting this part of the range is close to an exhumational steady state. In terms of spatial distribution, high rates of exhumation and denudation are localized in the hanging walls of major thrust faults, highlighting the role of tectonic structures in regulating the pattern of denudation and topography across the Longmen Shan. Our results favor the "brittle crustal shortening" model in which rock uplift pattern across the Longmen Shan is largely controlled by upper crustal shortening. Along-strike variations in the distribution of denudation rates and topography can probably be attributed to segmentation of subsurface fault structures.

\section{Introduction}

The Earth's topography results from the competition between internal processes driven essentially by tectonic fluxes and external forcing primarily affected by climate 
(Molnar \& England, 1990). Acting as a bridge linking these two forcings, surface processes provide a source of multiple feedback mechanisms (Champagnac et al. 2012). Analyzing the amplitude and distribution of surface erosion can provide important insights to understand tectonic processes and/or climatic variation. Moreover, surface erosion might play a critical role in defining the stress distribution and regional deformation by controlling topographic variations (Avouac \& Burov, 1996; Willett, 1999). Thus, in active mountain ranges, quantifying surface erosion is fundamental for understanding not only the uplift history and topographic evolution, but also geodynamic processes at depth.

Over recent decades, isotopic techniques have provided new approaches for the quantification of surface erosion processes, especially the widespread use of lowtemperature thermochronology (e.g., Reiners \& Brandon, 2006; Willett \& Brandon, 2013) and in situ produced cosmogenic nuclides (e.g., Lal, 1991; Stone, 2000). Lowtemperature thermochronology allows us to quantify the exhumation rate of rocks averaged over $10^{6}$-year timescale, based on the temperature-dependent diffusion or annealing in minerals (Reiners \& Brandon, 2006). Measurement of in situ produced cosmogenic nuclides in exposed rocks and fluvial sediment can provide local and catchment-wide denudation rates on a shorter time scale of $10^{2}-10^{5}$ years (Bierman \& Steig, 1996; Brown et al., 1995; Granger et al., 1996). When combined, these two methods can provide powerful spatiotemporal information on erosion rates (Kirchner et al., 2001).

The Longmen Shan range, located on the eastern margin of the Tibetan Plateau, is characterized by steep topography, with the average elevation rising from $\sim 600 \mathrm{~m}$ in the Sichuan Basin to $4000 \mathrm{~m}$ within the Tibetan Plateau over a horizontal distance of just $\sim 70 \mathrm{~km}$ (Figure 1). The sharp topographic front is mirrored by an abrupt change in crustal thickness, which increases from 40-45 km in the Sichuan Basin to $~ 60 \mathrm{~km}$ within the plateau (Robert et al., 2010). In contrast, no significant shortening across the entire Longmen Shan has been documented by geodesy (King et al., 1997; Royden et al., 1997; Zhang et al., 2004). This peculiar configuration has fueled controversies over how the topographic relief of the Longmen Shan was created and sustained. Several competing 
mechanisms have been proposed to explain the uplift of the Longmen Shan, in which brittle crustal shortening (e.g., Tapponnier et al., 2001) and middle-lower crust "channel flow" (e.g., Clark \& Royden, 2000) are considered two end-member models.

Quantifying surface erosion at different spatial and temporal scales, along with the deformation history of the crust, should help to clarify how the topography of the Longmen Shan was constructed and maintained. In the past few decades, hundreds of denudation and exhumation data, from million-year to decade-year timescale, were acquired from the Longmen Shan, and have contributed to advancing our understanding of the Cenozoic uplift history and surface erosion along the Longmen Shan. However, these data are highly heterogeneous in both spatial and temporal distributions. Most of them focus on long-term (Myr-scale) exhumation measured by low-temperature thermochronology (Ansberque et al., 2018; Arne et al., 1997; Cook et al., 2013; Godard et al., 2009; Kirby et al., 2002; Richardson et al., 2008; Shen et al., 2019; Tan et al., 2014; 2017; 2019; Tian et al., 2013; 2015; Wang et al., 2012; Wilson \& Fowler, 2011; Xu \& Kamp, 2000), while short-term denudation-rate estimates are comparatively less well documented, and most distributed along the Minjiang and Dadu river basins (Ansberque et al., 2015; Godard et al., 2010; Liu-Zeng et al., 2011; Ouimet et al., 2009). Except for a few results scattered throughout the Pengguan Massif (Godard et al., 2010), there is a lack of short-term denudation-rate data along the frontal range of the Longmen Shan, especially in its southern part. This uneven data distribution is an important limitation for our understanding of the variability of erosion processes in space and time across the Longmen Shan. Meanwhile, the Longmen Shan is characterized by strong lateral variations in topographic relief (e.g., Zhang et al., 2011), structural geometries (e.g., Jin et al., 2010), as well as seismicity (e.g., Yi et al., 2011). These differences directly reflect the heterogeneities of crustal thickening and topographic evolution along the Longmen Shan. Thus, it is necessary to constrain surface erosion in the different segments of the Longmen Shan, to explore its relevance to regional deformation, and to determine how erosion has influenced topographic variations along the range. 
Our study aims to fill this important knowledge gap with 25 new basin-averaged denudation results calculated from concentrations of in situ produced ${ }^{10} \mathrm{Be}$ in modern detrital river sediments from the southern Longmen Shan. Based on our new and previously published data, we aim to (1) document the magnitude and distribution of millennial-scale denudation rates across the southern Longmen Shan; (2) integrate the spatial variations in millennial-scale denudation rates with exhumation rates from lowtemperature thermochronology in the southern Longmen Shan as well as the central segment; and (3) explore the tectonic and geodynamic mechanisms associated with the evolution of the Longmen Shan.

\section{Geological background}

The bedrock geology of the Longmen Shan consists mainly of late Proterozoic crystalline basement (metavolcanic rocks and metasediments of the Yangtze craton) overlain by a Paleozoic passive margin sequence of metamorphosed sedimentary rocks and a thick Mesozoic foreland basin succession composed of marine and clastic sediments, accompanied by granitic intrusions with different crystallization ages. To the west, the Paleozoic substrate is overlain by the thick Triassic Songpan Garze flysch sequence (Figure 1; Burchfiel et al., 1995; Chengdu Institute of Geology and Mineral Resources, 2004).

The Longmen Shan has experienced a long history of deformation since the Mesozoic. In late Triassic to Jurassic time, the collision between the South China, North China, and Qiangtang blocks resulted in intense deformation of the Songpan Garze flysch, the emplacement of magmatic rocks, the development of a series of fold-andthrust belts along the western side of the Sichuan Basin, and the deposition of a suite of late Triassic to Cretaceous-Eocene sediments in the Sichuan Basin (Figure 1; Burchfiel et al., 1995; Chengdu Institute of Geology and Mineral Resources, 2004). Cenozoic outward growth of the Tibetan Plateau (e.g., Tapponnier et al., 2001), following the Indian-Eurasian continental collision, reactivated the preexisting Mesozoic fold-andthrust belt along the Longmen Shan (e.g., Yan et al., 2003). According to variations in 
the structural framework and tectonic evolution, the Longmen Shan can be divided into three segments (e.g., Jin et al., 2010). In the northern and central sections, the subparallel NE-striking Wenchuan, Beichuan, and Pengguan faults, from northwest to southeast, have well-documented Cenozoic activity (Figure 1; Chengdu Institute of Geology and Mineral Resources, 2004). In the southern section, the active structures are more complex and less clearly identified in the recent structural mapping. These structures include the Genda, Yanjin, and Dachuan faults, from northwest to southeast (Figure 1; Xu et al., 2016). Additionally, a series of Range Front Blind Thrust (RFBT) faults were developed in the western Sichuan Basin parallel to the mountain range ( $\mathrm{Li}$ et al., 2017; Wang et al., 2014). The faults along the northern Longmen Shan have often been considered less active during the late Cenozoic (e.g., Burchfiel et al., 1995), and thus we focus our study on the central and southern Longmen Shan. Low-temperature thermochronology data in the central Longmen Shan records at least two stages of rapid exhumation from 25 to $30 \mathrm{Ma}$ and since $\sim 10 \mathrm{Ma}$ (Wang et al., 2012). In the southern section, Cook et al. (2013) and Tian et al. (2013) proposed a phase of rapid exhumation since 10-17 Ma, and Tan et al. (2014) suggested a two-stage rapid exhumation with onsets at $230 \mathrm{Ma}$ and 3-5 Ma.

The Cenozoic deformation in the Longmen Shan is overprinted on the Mesozoic phase, and the two are difficult to separate (Figure 1). Previous studies suggested that the deformation of the upper crust in the Longmen Shan occurred mainly in the Mesozoic, and only a limited shortening of $\sim 10 \mathrm{~km}$ took place during the Cenozoic (e.g., Arne et al., 1997; Burchfiel et al., 1995; 2008). In contrast, Hubbard et al. (2010) estimated Cenozoic shortening on the order of $45 \mathrm{~km}$ in the foothills based on analyses of balanced geological cross-sections. Low-temperature thermochronological results suggest that exhumation across the Longmen Shan is controlled by the major structures observed at the surface. In the central Longmen Shan, the averaged long-term exhumation rates in the hanging wall of Beichuan and Wenchuan faults are much higher than that in their footwall, respectively, which indicates thrusting activity during the late Cenozoic (Tan et al., 2017; 2019; Tian et al., 2013). In the southern section, lowtemperature thermochronology studies also suggest structural controls on exhumation. 
For instance, an abrupt increase in exhumation rate (from 300 to $1700 \mathrm{~m} / \mathrm{m} . \mathrm{y}$.) across the Dachuan thrust fault underlines its activity during the late Cenozoic (Cook et al., 2013; Tan et al., 2014; Tian et al., 2013).

The thrusting activity of the Longmen Shan fault system during the Quaternary remains poorly constrained. Seismological studies show that the Beichuan and Pengguan faults are likely the most active in the central Longmen Shan, with an average throw rate of 0.1 to $1.0 \mathrm{~mm} / \mathrm{y}$ and 0.1 to $0.6 \mathrm{~mm} / \mathrm{y}$, respectively, during the late Quaternary (Densmore et al., 2007; Zhou et al., 2007). This activity was confirmed by the occurrence of the $M_{w} 7.9$ Wenchuan earthquake in 2008, which produced surface ruptures along these two faults (e.g., Liu-Zeng et al., 2009; Xu et al., 2009). In comparison, recent fault activity along the southern Longmen Shan is more ambiguous. The $2013 M_{w}$ 6.6 Lushan Earthquake ruptured a portion of the RFBT, but no surface rupture was observed (e.g., Xu et al., 2013). A few paleoseismic studies suggest that the Dachuan fault might have been active during the late Quaternary (e.g., Wang et al., 2015). However, fault slip rates in that part of the Longmen Shan are still poorly constrained.

\section{Methods}

\subsection{Sample collection, preparation, and analysis}

We collected 25 river sediment samples from active fluvial sandbars along rivers that drain the Southern Longmen Shan in April 2013, May 2017, and May 2018 (Figures 2, S1). The drainage upstream of sampling sites ranges from $18 \mathrm{~km}^{2}$ to 2770 $\mathrm{km}^{2}$. The bedrock geology of the catchments is diverse, including granite, volcanoclastic rock, gneiss, schist, phyllite, sandstone, and limestone (Figure S2). In the lab, the $0.25-1.00 \mathrm{~mm}$ size fraction was separated and purified until obtaining pure quartz through standard magnetic and chemical techniques. The samples were then dissolved in concentrated HF after addition of a ${ }^{9} \mathrm{Be}$ carrier, following the procedures described by Brown et al. (1991). ${ }^{10}$ Be analyses were performed at the French AMS national facility ASTER (Arnold et al., 2010). The isotopic ratios were calibrated 
against the National Institute of Standards and Technology standard reference material 4325 , using the values determined by Nishiizumi et al. (2007), with a specified ${ }^{10} \mathrm{Be} /{ }^{9} \mathrm{Be}$ ratio of $2.79 \pm 0.03 \times 10^{-11}$ and $\mathrm{a}^{10} \mathrm{Be}$ half-life of $1.36 \pm 0.07 \times 10^{6}$ years. The analytical uncertainties (reported as $1 \sigma$ ) include a $1.08 \%$ uncertainty on the certified standard ratio, a $1 \sigma$ uncertainty associated with the chemical blank measurement, a $1 \sigma$ statistical error on AMS counting, and a conservative $0.5 \%$ external machine uncertainty (Arnold et al., 2010).

\subsection{Computation of denudation rates from measured ${ }^{10} \mathrm{Be}$ concentrations}

At steady-state, the surface nuclide concentration of an eroding bedrock or soil approaches a secular equilibrium, and is inversely proportional to the denudation rate. If fluvial sediment can be regarded as resulting from a homogeneous mixing of grains from the upstream area, its nuclide concentration can be used to quantify the basin-wide average denudation rate (Bierman \& Steig, 1996; Brown et al., 1995; Granger et al., 1996):

$$
\bar{N}=\frac{\Sigma N_{i} E_{i} A_{i}}{\Sigma E_{i} A_{i}}=\frac{\Sigma\left(P_{i} \Lambda / \rho\right) A_{i}}{\Sigma E_{i} A_{i}}=\frac{\Lambda \overline{P_{0}}}{\rho \bar{E}}
$$

where $\overline{\mathrm{E}}$ and $\bar{N}$ are the basin-wide average denudation rate and nuclide concentration, respectively; $\rho$ and $\Lambda$ are rock density $\left(\mathrm{g} \cdot \mathrm{cm}^{-3}\right)$ and attenuation length $\left(\mathrm{g} \cdot \mathrm{cm}^{-2}\right)$, respectively; and $P_{0}$ is basin averaged nuclide production rate (atoms $\cdot \mathrm{g}^{-1} \cdot \mathrm{yr}^{-1}$ ) at the surface, which was determined by:

$$
\overline{P_{0}}=\frac{1}{A} \iint_{x, y} P_{i}(x, y) \times F_{\text {topo }}(x, y) \times d x d y
$$

in which $\mathrm{A}$ is the basin area, $P_{i}(x, y)$ is the local production rate at each point of the basin, and $F_{\text {topo }}(x, y)$ is topographic shielding factor integrated over the basin surface. ${ }^{10} \mathrm{Be}$ production rates by spallation and muons were scaled for latitude and local altitude according to Lal (1991) and Stone (2000), and corrected for topographic shielding according to Dunne et al. (1999). Here, we used a sea level high latitude production rate 
of $4.01 \pm 0.35$ atoms $\cdot \mathrm{g}^{-1} \cdot \mathrm{yr}^{-1}$ (Borchers et al., 2016; Phillips et al., 2016) and a muon contribution of $0.028 \pm 0.004$ atoms $\cdot \mathrm{g}^{-1} \cdot \mathrm{yr}^{-1}$ (Braucher et al., 2011; 2013). The attenuation length for spallation $\left(\Lambda_{s p a}\right)$ and muons $\left(\Lambda_{m u}\right)$ are $160 \mathrm{~g} \cdot \mathrm{cm}^{-2}$ and 4200 $\mathrm{g} \cdot \mathrm{cm}^{-2}$, respectively (Braucher et al., 2013; Granger \& Smith, 2000). We also recalculated denudation rates from previously published ${ }^{10} \mathrm{Be}$ data (Figure S1; Ansberque et al., 2015; Godard et al., 2010; Ouimet et al., 2009) to be consistent with the production rate and scaling parameters adopted here.

\subsection{Computation of exhumation rates from thermochronological data}

In order to compare the denudation rates over different timescales along the Longmen Shan, we have calculated million-year timescales exhumation rates based on the published apatite fission-track (AFT) and He (AHe) data (Figure S3). An eroding half-space model (Willett \& Brandon, 2013) was used to convert thermochronometric ages to exhumation rates. The surface temperature is set at $15^{\circ} \mathrm{C}$, and the geothermal gradient is assumed to be $25^{\circ} \mathrm{C} \cdot \mathrm{km}^{-1}$ (Tan et al., 2017). For AHe data, we used the following kinematic parameters: activation energy $\mathrm{E}_{\mathrm{A}}=138 \mathrm{~kJ} \cdot \mathrm{mol}^{-1}$, frequency factor $\Omega=7.64 \times 10^{7} \mathrm{~s}^{-1}$, closure temperature $\mathrm{T}_{\mathrm{c} 10}=67^{\circ} \mathrm{C}$ (Farley, 2002). For AFT data, we used $\mathrm{E}_{\mathrm{A}}=147 \mathrm{~kJ} \cdot \mathrm{mol}^{-1}, \Omega=2.05 \times 10^{6} \mathrm{~s}^{-1}, \mathrm{~T}_{\mathrm{c} 10}=116^{\circ} \mathrm{C}($ Ketcham et al., 1999).

\subsection{Topographic, climatic and vegetation analysis}

To identify landscape and climate controls on denudation rates, we analyzed various standard geomorphic and climatic metrics along the Longmen Shan range, particularly in the southern and central sections (Figure 3).

Geomorphic analyses were based on ASTER Global Elevation Maps (ASTER GDEM is a product of Japan's Ministry of Economy, Trade, and Industry (METI) and NASA, with $30 \mathrm{~m}$ resolution). Hillslope gradient was calculated pixel by pixel using a $3 \times 3$ pixel moving window and then averaged over the upstream basin to get the basinaveraged mean value. Error bars on mean basin slope were fixed at \pm 2.25 degrees, as suggested by Ouimet et al. (2009). Topographic relief of each catchment was calculated 
by a scale-dependent analysis of the mean local relief using a 1-km diameter circular window. Mean annual precipitation was calculated based on monthly climatic data from WorldClim version 2 (http://worldclim.org/version2) with a temporal coverage from 1970-2000, and a $1 \times 1 \mathrm{~km}$ spatial grid resolution (Fick \& Hijmans, 2017).

We used the normalized steepness index $\left(k_{s n}\right)$ and specific stream power (SSP) as two proxies to document the relative intensity of fluvial incision along the rivers. We computed the normalized steepness index, $k_{s n}$, of all channels with drainage area larger than $1 \mathrm{~km}^{2}$, adopting a reference concavity $\theta_{\text {ref }}$ of 0.40 based on the area-slope relationship for the drainages of the Eastern Tibet (Figure S4). We then averaged all $k_{s n}$ values in each basin to get the basin-averaged value and report the standard deviation around this value. Specific stream power (SSP) reflects the conversion of the gravitational potential energy of flowing water to either incise the river bed or transport sediment (Whipple \& Tucker, 1999). It is calculated as $\Omega=\rho_{w} g S Q_{w} / W$, where $\Omega$ is the specific stream power $\left(\mathrm{W} \cdot \mathrm{m}^{-2}\right), \rho_{\mathrm{w}}$ and $\mathrm{g}$ are the specific weight of water $\left(1000 \mathrm{~kg} \cdot \mathrm{m}^{-3}\right)$ and gravitational acceleration $\left(9.81 \mathrm{~m} \cdot \mathrm{s}^{-2}\right)$, respectively. $\mathrm{S}$ is the channel gradient $\left(\mathrm{m} \cdot \mathrm{m}^{-1}\right)$ extracted from GDEM data. $\mathrm{Q}_{\mathrm{w}}$ is the water discharge $\left(\mathrm{m}^{3} \cdot \mathrm{s}^{-1}\right)$, which is calculated as the product of upstream area and mean annual precipitation. We used a width-discharge scaling relationship of $\mathrm{W}=10 \mathrm{Q}_{\mathrm{w}}{ }^{0.5}$ (Montgomery \& Gran, 2001; Tucker \& Hancock, 2010). Procedures to perform the calculations were implemented using the MATLAB-based software package Topo Toolbox version 2.0 (Schwanghart \& Scherler, 2014).

We also quantified vegetation density along the Longmen Shan using the normalized difference vegetation index (NDVI) to understand the possible impact of vegetation on denudation rates. NDVI is a remotely-sensed measure of vegetation density derived from the MODND data set, which is provided by Geospatial Data Cloud, Computer Network Information Center, Chinese Academy of Sciences (http://www.gscloud.cn), with a spatial resolution of $500 \mathrm{~m}$. Valid values of NDVI range from -1 to 1 , in which negative values indicate cloud, water, or snow areas, 0 for bare land, and 1 for extremely dense vegetation cover. Employing 7 years (2001-2007) of available MODND vegetation indices, we calculated mean annual, summer (May to 
October), and winter (November to April) NDVI values along the Longmen Shan. We also calculated a seasonality index (SI) to quantify the difference between summer and winter vegetation, which is derived from the division of summer NDVI by winter NDVI (Olen et al., 2016).

Previous studies show that the lithological erodibility may have a strong effect on erosion rates (e.g., Schmidt \& Montgomery, 1995). In this paper, we adopted the global averaged rock erodibility index (EI) suggested by Moosdorf et al. (2018) to account for the effects of lithology on surface erosion: Granitic, metamorphic, and carbonate sedimentary rocks have an EI value of 1.0; the basic volcanic rocks and siliciclastic rocks are assigned EI values of 1.4 and 1.5, respectively; and unconsolidated sediments (for example quaternary deposits) have an EI value of 3.2. Hereby, a high EI value indicates both high sensitivity to weathering and low compressive strength. Abrasion experiments on lithologies of the Longmen Shan conducted by Godard et al. (2010) give a similar pattern, in which granitoids and metamorphic rocks have lower abrasion rates and Paleozoic-Mesozoic sediments present a wider and higher range of abrasion rates. The EI values were obtained at the catchment scale by weighting the mean EI of the different lithologies with their relative area on the geological map.

\section{Results}

\subsection{Topography and Climate}

Across the Longmen Shan, topographic steepness metrics (e.g., hillslope angle, local relief, and normalized channel steepness) increase in general from the Sichuan Basin northwestward into the Tibetan Plateau, and show clear breaks across active structures such as Dachuan and Beichuan faults (Figures 3a-c). In the southern Longmen Shan, hillslope angle and 1-km-radius local relief of the sampled catchments are between $12^{\circ}$ and $33^{\circ}$, and $291 \mathrm{~m}$ and $946 \mathrm{~m}$, respectively. The normalized channel steepness index, $k_{s n}$, ranges from 31 to $224 \mathrm{~m}^{0.8}$ (Table 1). The lowest values of these steepness metrics are all found in catchments that are located in the footwall of the 
Range Front Blind Thrust, and the highest values are found in the catchments in the hanging wall of the Dachuan fault.

Due to the steeply rising topographic front that forces moist air masses to rise, the southern Longmen Shan has higher precipitation compared to the central section (Figure 3d). The average annual rainfall in our sampled catchments is between 780 and $1410 \mathrm{~mm}$ (Table 1). However, specific stream power (SSP) does not show a positive correlation with rainfall. The SSP is relatively low in the southern Longmen Shan, especially compared to values along the trunks of the Minjiang River (Figure 3e). The average SSP in our sampled catchments is in the 14 to $81 \mathrm{~W} \cdot \mathrm{m}^{-2}$ range (Table 1 ).

The normalized difference vegetation index (NDVI) and seasonality index (SI) are both strongly controlled by elevation in Eastern Tibet (Figures 3g-h). In the southern Longmen Shan, catchment-averaged NDVI and SI span narrow ranges of $0.42-0.58$ and $0.88-1.48$ (both dimensionless), respectively (Table 1). Rock erodibility is relatively high in the Sichuan Basin and the interior of the plateau, as sedimentary rocks are outcropping in both regions (Figure 2). The frontal range of the Longmen Shan mainly consists of crystalline basement and granitic rocks and thus presents lower erodibility (Figure 3f). The averaged dimensionless rock erodibility in the sampled catchments is between 1.0 and 1.7 (Table 1).

\section{2 ${ }^{10} \mathrm{Be}$ concentrations and catchment-wide denudation rates}

The ${ }^{10} \mathrm{Be}$ concentration results and calculated denudation rates are shown in Table 2 and Figure 2 . The measured ${ }^{10} \mathrm{Be}$ concentrations in the detrital sand samples range from $2.2 \times 10^{4}$ to $12.7 \times 10^{4}$ atoms/g. The corresponding catchment-wide denudation rates vary by one order of magnitude from 0.05 to $0.69 \mathrm{~mm} / \mathrm{y}$, a similar range as in the central Longmen Shan (Godard et al., 2010). To first order, the drainage basins that are located in the footwall of Range Front Blind Thrust are eroding with rates lower than $0.15 \mathrm{~mm} / \mathrm{y}$, whereas basins in the hanging wall of the Dachuan fault have higher denudation rates. We obtained the highest denudation rate $(>0.5 \mathrm{~mm} / \mathrm{y})$ in basins that are located in the hanging wall of the Yanjin fault. 


\subsection{Correlation between denudation rate and topographic and climatic}

\section{parameters}

In general, the ${ }^{10} \mathrm{Be}$-derived catchment-wide denudation rates in the southern Longmen Shan correlate positively with the morphometric indices and appear independent of climatic and lithological differences (Figure 4).

As observed along the Dadu and the Minjiang rivers (Ouimet et al., 2009; Ansberque et al., 2015), the relationship between denudation rate and catchment mean slope in the southern Longmen Shan is nonlinear, as proposed by Roering et al. (2001) (Figure 4a). Denudation rates are positively correlated with local relief, $k_{s n}$, and specific stream power, with substantial scatter, which makes it difficult to assess the degree of non-linearity of the relationship (Figures $4 \mathrm{~b}$, c, and e). We also note that, compared to the denudation rates from the Dadu River (Ouimet et al., 2009), the results from the Minjiang watershed (Ansberque et al., 2015) and our data both present higher denudation rates for a given slope, local relief, $k_{s n}$, as well as specific stream power.

Our sampled basins show a negative correlation between annual rainfall and denudation rate (Figure $4 \mathrm{~d}$ ), which indicates that greater precipitation does not cause higher surface erosion rate in the southern Longmen Shan, or that a more complex coupling between precipitation, vegetation, and denudation is involved. The weak inverse correlation between rock erodibility and denudation, which is contrary to expectations (e.g., Godard et al., 2010), indicates that the spatial variability of lithology has a negligible influence on the denudation rate (Figure 4f). Finally, the relationship between catchment-wide denudation and vegetation coverage or its variation is also not straight-forward (Figures 4g-h). Therefore, vegetation cover does not appear to be important for explaining variations in observed denudation rates. 


\section{Discussion}

\subsection{Uncertainties on ${ }^{10} \mathrm{Be}$-derived denudation rates}

Before interpreting spatial variations in erosion rates, we need to assess the sources of uncertainty of denudation rates derived from inventories of detrital ${ }^{10} \mathrm{Be}$. We therefore first discuss some of the factors for which we lack significant constraints, and their potential impacts.

At the catchment scale, lithological contrast is one of the major factors that could affect the ${ }^{10} \mathrm{Be}$ concentration in the river sediment and thus the interpreted denudation rate. The disparity in quartz content in different rock types is likely to prevent proper weighting of basin-scale production rates of ${ }^{10} \mathrm{Be}$ (e.g., Granger et al., 1996). The rock type in the Longmen Shan ranges from quartz-rich Proterozoic crystalline basement and granitoids to quartz-poor carbonate and mafic rocks (Figures 1 and S2). To evaluate the influence of such heterogeneity in quartz distribution, we have recalculated the ${ }^{10} \mathrm{Be}$ production rates and the denudation rates by weighting each DEM pixel by the proportion of quartz in the underlying lithology when calculating basin-average ${ }^{10} \mathrm{Be}$ production rates (The estimated proportions of quartz are: Granitoid rocks: 25\%; Sedimentary rocks: 5\%; Carbonate and mafic rocks: 0\%; Figure S2). The differences between our initial un-corrected denudation rates and those including this lithological correction are minor (Figure 5). As the exact quartz content in each lithology is unknown, and the sources of quartz might be influenced by the diversity of denudation rate, grain sizes, and chemical weathering from different rock types, we prefer to use the denudation rates uncorrected for lithology in the following discussion. Within the resolution of our data, variations in quartz content appear to have a negligible effect on estimates of denudation rate within the Longmen Shan.

Systematic overestimation of denudation rates can occur if most denudation results from infrequent landslides (Niemi et al., 2005; Ouimet, 2010; West et al., 2014; Wang et al., 2017). However, the impacts of the 2008 Wenchuan and the 2013 Lushan earthquakes were likely minor for our samples. The landslides caused by the Wenchuan 
earthquake were mostly distributed in the central Longmen Shan, and there were few in the southern part of the range (e.g., Xu et al., 2014). The Lushan earthquake caused some landslides in our study catchments, but most of them are rockfalls, and their amount and area are both limited (e.g., Tang et al., 2015). The drainage basin most impacted by landsliding is located upstream of Baosheng Town, which includes our catchments 01, 02, 03, and 05 (Figure 2; Tang et al., 2015). However, the obtained detrital ${ }^{10} \mathrm{Be}$ concentrations in these catchments are relatively high compared to surrounding areas (Table 2), which argues against dilution by the injection of landslidederived, low-concentration material (West et al., 2014; Wang et al., 2017). A similar observation was also made in the Himalayas, where detrital ${ }^{10} \mathrm{Be}$ concentrations did not exhibit clear changes before and after the $M_{w} 7.8$ Gorkha earthquake (Schide et al., 2019). We thus conclude that landsliding caused by the Lushan Earthquake has a negligible or minor influence on ${ }^{10} \mathrm{Be}$ concentrations in our samples.

\subsection{Potential influence factors on denudation rate in the southern Longmen}

\section{Shan}

Our results show a clear inverse correlation between catchment-averaged precipitation and denudation rates (Figure 4d), similar to previous observations in southeastern Tibet (Schmidt et al., 2018). These findings demonstrate that upstream precipitation rate does not promote denudation in the southern Longmen Shan. Another indirect influence of climate on denudation is its control on vegetation distribution. Vegetation cover limits denudation rates by increasing soil resistance and protecting the surface from rain splash (e.g., Gyssels et al., 2005). Furthermore, the presence of vegetation increases evapotranspiration and thus reduces the amount of runoff (e.g., Rossi et al., 2016). However, neither the vegetation density (NDVI) nor its seasonal variation (SI) shows any systematic relation with denudation rates in our study (Figures 4g-h). Although we have not considered the impact of runoff variability on river incision (e.g., Lague et al., 2005; Sklar \& Dietrich, 1998), the regional differences in discharge variability in Eastern Tibet are minor and cannot account for the spatial 
variation of denudation rates along the Longmen Shan (Liu-Zeng et al., 2011; Scherler et al., 2017). Overall, we suppose that the spatial variations in precipitation and vegetation cover are not dominant factors for explaining the observed variations in denudation rates.

In contrast with climatic factors, all topographic parameters present a moderate and positive relationship with denudation rates reported in our study. As in many tectonically active mountain ranges (e.g., Binnie et al., 2007; DiBiase et al., 2010; Montgomery \& Brandon, 2002; Ouimet et al., 2009; Roering et al., 2001), the steepest topography of the southern Longmen Shan is characterized by threshold hillslope angles at $\sim 37^{\circ}$ (Figure $4 \mathrm{a}$ ). Above the threshold, mass wasting processes such as landsliding likely control surface erosion, limit topographic gradient, and decouple hillslope angles from denudation rates (e.g., Larsen \& Montgomery, 2012; Ouimet et al., 2009). Compared with hillslopes, the longitudinal profiles of bedrock channels might be more sensitive to denudation rate in active mountain ranges (e.g., Kirby \& Whipple, 2012). Our data present a moderately strong $\left(\mathrm{R}^{2}=0.44\right)$ linear relationship between channel steepness, $k_{s n}$, and denudation rates. A power-law model gives a slightly better fit, especially in the high denudation range $\left(\mathrm{E} \approx\left[k_{s n}\right]^{\mathrm{n}}\right.$ with $\mathrm{n}=1.8 ; \mathrm{R}^{2}=$ 0.50; Figure 4c). Specific stream power (SSP), which combines channel gradient with water discharge, yields a similar fit $\left(\mathrm{R}^{2}=0.46\right.$; Figure 4e). Ouimet et al. (2009) argued that the nonlinear behavior of channel incision along the Dadu River $\left(\mathrm{E} \approx\left[k_{s n}\right]^{\mathrm{n}}\right.$ with $\mathrm{n}>$ 1) might result from the combined effects of a critical threshold of motion and detachment and the probability distribution of flood magnitudes and durations, which induce more efficient erosion in steeper channels. These dynamics may affect the high denudation rates in the southern Longmen Shan. We also found a strong, positive linear correlation between hillslope angles and $k_{s n}$ in the Longmen Shan as well as along Minjiang and Dadu rivers $\left(\mathrm{R}^{2}=0.74\right.$; Figure S5), which suggests that channel and hillslope erosion are approximately coupled in Eastern Tibet (e.g., Mandal et al., 2015).

Similar to previous studies in other regions (e.g., Montgomery \& Brandon, 2002; Korup \& Weidinger, 2011), our results exhibit a fair degree of scatter when comparing topographic metrics and denudation rates, particularly at high values (Figure 4). 
Variations in rock mass strength and quality can complicate these functional relationships, and control threshold hillslope angles across the Longmen Shan, as observed in the Himalayas (Korup \& Weidinger, 2011). Godard et al. (2010) proposed that steep topography along the central Longmen Shan could be attributed to the high rock strength of the Pengguan massif. However, the observation that variations in stream gradient are not significantly correlated with lithological variations (Kirby \& Ouimet, 2011) argue against this inference. Our study also shows no indication that rock erodibility substantially alters the functional relationship between denudation rate and topography (Figure 6a). The integrated effect of fractures, joints, and other discontinuities also acts to weaken rock at increasing spatial scale (e.g., Schmidt \& Montgomery, 1995). In this situation, tectonic and/or climatically controlled cohesion might be setting the limits on the near-surface rock strength along the Longmen Shan (Gallen et al., 2015). Variable erodibility may explain some of the scatter we observed (Kirkpatrick et al., 2021), but additional field constraints are needed to test this possibility.

Besides rock strength, another major source for the scatter between topographic and denudation observations is spatial variations in climate. Olen et al. (2016) hypothesized that the variability in denudation rates along-strike of the Himalaya is related to differences in vegetation density and vegetation seasonality. However, we have not observed clear evidence that precipitation, NDVI, or SI changed the functional relationship between denudation rate and $k_{s n}$ in our study, even when including the previous results along the Minjiang and Dadu rivers (Figures 6b-d). This lack of control might be attributed to the limited variability in precipitation and vegetation density in the Longmen Shan range when compared with the Himalayas. Other factors that could impact the $k_{s n}$-denudation rate relationship, including the grain size distribution of river sediments (e.g., Sklar \& Dietrich, 1998) and duration or strength of summer monsoon precipitation (e.g., Scherler et al., 2017), were not considered in our study, and need more exploration and detailed field observations.

In summary, although lithological and climatic fluctuations might modulate denudation rates, topographic indices are the best predictors of the denudation rates in 
the southern Longmen Shan, as well as along the Minjiang and Dadu rivers (Ansberque et al., 2015; Ouimet et al., 2009).

\subsection{Spatial relationship between active faults, denudation, and topography}

\section{across the Longmen Shan}

The close relationship between denudation rate and topography across the southern Longmen Shan is more clearly expressed with swath profiles perpendicular to the strike of the range (Figure 7). Surface elevation, hillslope gradient, channel steepness, as well as ${ }^{10} \mathrm{Be}$-derived denudation rates show very similar distributions, increasing from the Sichuan Basin towards the interior of the Tibetan Plateau (Figures 7a-c). When compared with subsurface structures (Li et al., 2017; Xu et al., 2016), we notice that variations of those indices coincide spatially with active faults (Figures 2 and 7a-c). Previous paleoearthquake studies indicated that the Dachuan fault might be the most active fault in the southern Longmen Shan during the Holocene (Wang et al., 2015). This inferred activity is consistent with the abrupt increase in denudation rates from $\sim 0.1 \mathrm{~mm} / \mathrm{y}$ up to $\sim 0.5 \mathrm{~mm} / \mathrm{y}$ across the Dachuan fault in our study (Figure 7a). Northwest of the Genda fault, the ${ }^{10} \mathrm{Be}$-derived denudation rates derived from the Dadu river decrease gradually, although topography remains steep (Ouimet et al., 2009; Figures 7a-c). Integrating over longer time scales, AHe- and AFT-derived exhumation rates, based on an eroding half-space model (Willett \& Brandon, 2013), display a comparable trend, increasing from $0.01 \mathrm{~mm} / \mathrm{y}$ in the footwall of the Dachuan fault up to $\sim 0.75 \mathrm{~mm} / \mathrm{y}$ in the hanging wall of the Yanjin fault (Figure 7d). ZHe and ZFT dating also present a similar trend (Figure 7e). In this particular setting, we interpret the apparent spatial correlation between denudation rates and active faults as evidence for a primary tectonic control on the erosion patterns and landscape evolution across the southern Longmen Shan.

Moving northeast to the central Longmen Shan, the frontal mountain range presents steep topography, but relatively low millennial-scale denudation rates, which were captured before the $2008 \mathrm{M}_{\mathrm{w}} 7.9$ Wenchuan earthquake (Godard et al., 2010; 
Figures 7f-h). In comparison, low-temperature thermochronology data show higher average exhumation rates over a longer time scale in the hanging wall of Beichuan and Wenchuan faults (Figures 7i-j). River sediment load data before the Wenchuan earthquake delineate a zone of relatively rapid denudation over decadal-timescales along the frontal range (Liu-Zeng et al., 2011). We thus suppose that the ${ }^{10} \mathrm{Be}$-derived denudation rates along the front of the central Longmen Shan might be underestimated, as they do not account for the co-seismic erosion caused by Wenchuan-type earthquakes (Godard et al., 2010; Ouimet, 2010). The constancy of exhumation rates over decadal- and Myr-year timescales show that denudation rates might be relatively constant over several million years along the central Longmen Shan (Liu-Zeng et al., 2011). In addition, coseismic deformation of the 2008 Wenchuan earthquake and paleoseismic events highlight that the Beichuan fault behaves as thrust fault with a dextral strike-slip component during the late Quaternary (e.g., Densmore et al., 2007; Liu-Zeng et al., 2009; Ran et al., 2010; Xu et al., 2009). Thus, the abrupt increase of denudation rates and topographic steepness in the hanging wall of the Beichuan fault demonstrate the potential influence of this active structure on erosion and topography across the margin of the central Longmen Shan.

Overall, our results support a consistency of erosion rates over millennial to million-year timescales across the southern and central Longmen Shan (Figure 7), indicating that the margin of the eastern Tibetan Plateau may have reached an exhumational steady state for at least the last several millions of years (Liu-Zeng et al., 2011), and the topography and erosion have adjusted to the ongoing rock uplift. In light of such high spatial consistency in fault locations, topography, and erosion rates over different timescales, we argue that the activities of faults significantly control surface erosion across the Longmen Shan, which is broadly similar to other observations along the southern and northeastern Tibetan Plateau margins (e.g., Godard et al., 2014; Hetzel, 2013; Scherler et al., 2014). 


\subsection{Implications for Eastern Tibet tectonics and topographic evolution}

The most striking feature of the Longmen Shan range is the coexistence of low shortening rates in the upper crust as seen by geodesy (e.g., Zhang et al., 2004) and high topographic gradients. The lower crustal "channel flow" model argues that the eastward flow of weak crust material from the interior of the Tibetan Plateau has been obstructed by the strong and craton-like crust/lithosphere of the Sichuan Basin (Royden et al., 1997; Clark \& Royden, 2000; Clark et al., 2005; Cook \& Royden, 2008). It thus leads to upward inflation of the lower crust and uplift of the Longmen Shan range, without requiring large-scale shortening of the upper crust. Despite slow convergence and stress accumulation rates, the occurrence of the $M_{w} 7.9$ Wenchuan earthquake demonstrates the strong thrusting activity of structures in the upper crust along the Longmen Shan (e.g., Jia et al., 2010; Liu-Zeng et al., 2009; Xu et al., 2009). Multiple studies also suggest that upper crustal deformation alone can completely explain the crustal thickening and topographic building of the eastern Tibetan Plateau margin during the Cenozoic (Godard et al., 2009; Hubbard \& Shaw, 2009; Hubbard et al., 2010; Liu-Zeng et al., 2011; Tian et al., 2013).

In our study, the high consistency in erosion rates over millennial and million-year timescales indicates a topographic steady state across the front range of the southern and central Longmen Shan (Figure 7). In this situation, erosion rates can be used to track rock uplift patterns (e.g., Willett \& Brandon, 2002). Across the southern Longmen Shan, high uplift areas, as identified by high denudation and exhumation rates, are located in the hanging wall of the Dachuang and Yanjing faults (Figures 7a, e, and 8a). In the central segment, the ${ }^{10} \mathrm{Be}$-derived denudation rate pattern is ambiguous (Figure 7f), but low-temperature thermochronometric ages indicate two high exhumation zones in the hanging wall of the Beichuan and Wenchuan faults, respectively (Figures 7i and 8c). Godard et al. $(2009,2010)$ have proposed that the eastward increase of exhumation in the hanging wall of the Wenchuan fault was caused by a transient wave of regressive erosion propagating across the margin. This may explain the broad, high exhumation zone and the decoupling between long- and short- term denudation/exhumation rates 
towards the interior of Tibet (Figure 8c). However, the abrupt increase in exhumation across the Wenchuan fault cannot be caused by regressive erosion, and is more likely related to a high uplift zone in its hanging wall (Shen et al., 2019; Tian et al., 2013).

The lower crustal channel flow model predicts a broadly distributed, continuous deformation at the surface (Clark \& Royden, 2000; Clark et al., 2005), or a narrow uplift zone bounded by frontal thrusting and hinterland extension architecture (Burchfiel et al., 2008; Ouimet, 2010). Both versions of this model are difficult to reconcile with the along-strike variability in uplift patterns from the southern to central Longmen Shan, and the existence of two high uplift zones across the central segment (Figures 8a and c). Instead, such uplift patterns are consistent with the upper crustal architecture observed by geophysical surveys (Figures $8 \mathrm{~b}$ and d). Seismic reflection data show that the Longmen Shan fault zone is composed of a series of west-dipping reverse faults that root into a sub-horizontal decollement at $\sim 20 \mathrm{~km}$ depth (e.g., Hubbard \& Shaw, 2009; Jia et al., 2010; Li et al., 2017). These high uplift zones are both located above the ramp of the active faults across the southern and central Longmen Shan, which agrees with the deformation pattern based on the fault-bend folding theory (Figure 8; Suppe, 1983).

A recent microstructural study of fault rocks from the "Wenchuan Earthquake Fault Scientific Drilling" cores has demonstrated the long-term seismic activity of the Beichuan fault (Wang et al., 2019), which highlights the role of high-angle listric reverse faulting of the Longmen Shan fault system in transferring horizontal deformation into vertical displacement (e.g., Zhang, 2013). We suppose that the spatial pattern of uplift across the Longmen Shan is largely controlled by upper crust deformation (Figure 8), although plastic thickening of the lower crust might also contribute to the uplift of the larger Eastern Tibet area (e.g., Robert et al., 2010; Tan et al., 2019; Zhang, 2013). Detailed structural and thermobarometic data suggest that present-day fault segmentation along the southern and central Longmen Shan probably had been established since the Mesozoic mountain building (Airaghi et al., 2018). Different geometry of these inherited faults and structures between the southern and central segments of the Longmen Shan might be the primary causes for the along-strike 
variations in denudation patterns and topographic evolution observed in our study (Figures 7-8).

\section{Conclusion}

Our 25 new catchment-wide denudation rates derived from ${ }^{10} \mathrm{Be}$ concentration in river sediments across the southern Longmen Shan fill an important gap in the documentation of denudation rates along the eastern Tibetan Plateau margin. Our analysis shows that topographic metrics are the best predictors of the variations in these millennial-scale denudation rates in the southern Longmen Shan as well as along the Minjiang and Dadu rivers, and that precipitation, lithology, and vegetation are secondorder modulating factors.

Our cosmogenic and thermochronologic data compilation shows that millennialscale denudation rates broadly agree with long-term exhumation rates, which suggests that the Longmen Shan has achieved an exhumational steady state, which implies that topography and erosion are adjusted to the ongoing rock uplift. The high spatial consistency in the locations of active structures, topography, and erosion rates over different timescales indicates that fault activity strongly regulates surface erosion across the Longmen Shan.

The patterns of denudation rate across the southern and central Longmen Shan both support the idea that the mountain belt has probably developed by the classic mechanism of upper-crustal faulting and folding. Our findings highlight the role of upper crustal shortening in inducing enhanced denudation and forming the steep topography in Eastern Tibet. We also suggest that along-strike variations in denudation patterns and topography can be attributed to the evolution of the main structures responsible for deformation in the different segments of the Longmen Shan.

\section{Acknowledgments}

This work was supported by the National Natural Science Foundation of China (41902215, 42030305, 41772209), and Funds for International Cooperation and 
Exchange of the National Natural Science Foundation of China (41761144065). The

${ }^{10} \mathrm{Be}$ measurements were performed at the ASTER AMS national facility (CEREGE, Aix en Provence) which is supported by the INSU/CNRS, the ANR through the "Projets thématiques d'excellence" program for the "Equipements d'excellence" ASTERCEREGE action and IRD. We also thank Amanda Schmidt, Eric Kirby, and Editor Taylor Schildgen for constructive comments and suggestions that improved the quality of this paper. Six additional figures are included in the supporting information for this article. All cosmogenic and thermochronologic data used in this study are available in a Mendeley Data database: http://dx.doi.org/10.17632/8cwnszbyrg.1

\section{References}

Airaghi, L., J. de Sigoyer, S. Guillot, A. Robert, C. J. Warren, and D. Deldicque (2018). The Mesozoic Along-Strike Tectonometamorphic Segmentation of Longmen Shan (Eastern Tibetan Plateau). Tectonics, 37(12), 4655-4678. https://doi.org/10.1029/2018TC005005

Ansberque, C., V. Godard, O. Bellier, J. De Sigoyer, J. Liu-Zeng, X. Xu, Z. Ren, Y. Li, and A. Team (2015). Denudation pattern across the Longriba fault system and implications for the geomorphological evolution of the eastern Tibetan margin. Geomorphology, 246, 542-557. https://doi.org/10.1016/j.geomorph.2015.07.017

Ansberque, C., V. Godard, V. Olivetti, O. Bellier, J. Sigoyer, M. Bernet, K. Stübner, X. Tan, X. Xu, and T. A. Ehlers (2018). Differential Exhumation Across the Longriba Fault System: Implications for the Eastern Tibetan Plateau. Tectonics, 37(2), 663-679. https://doi.org/10.1002/2017TC004816

Arne, D., B. Worley, C. Wilson, S. F. Chen, D. Foster, Z. L. Luo, S. G. Liu, and P. Dirks (1997). Differential exhumation in response to episodic thrusting along the eastern margin of the Tibetan Plateau. Tectonophysics, 280(3-4), 239-256. https://doi.org/10.1016/S0040-1951(97)00040-1

Arnold, M., S. Merchel, D. L. Bourlès, R. Braucher, L. Benedetti, R. C. Finkel, G. Aumaître, A. Gottdang, and M. Klein (2010). The French accelerator mass spectrometry facility ASTER: improved performance and developments. Nuclear Instruments and Methods in Physics Research Section B: Beam Interactions with Materials and Atoms, 268(11), 1954-1959. https://doi.org/10.1016/j.nimb.2010.02.107

Avouac, J. P., and E. B. Burov (1996). Erosion as a driving mechanism of intracontinental mountain growth. Journal of Geophysical Research Solid Earth, 101(B8), 17747-17769. https://doi.org/10.1029/96JB01344

Bierman, P., and E. J. Steig (1996). Estimating rates of denudation using cosmogenic isotope abundances in sediment. Earth Surface Processes and Landforms, 21(2), 125-139. https://doi.org/10.1002/(SICI)1096-9837(199602)21:2<125::AID-ESP511>3.0.CO;2-8

Binnie, S. A., W. M. Phillips, M. A. Summerfield, and L. K. Fifield (2007). Tectonic uplift, threshold hillslopes, and denudation rates in a developing mountain range. Geology, 35(8), 743-746. https://doi.org/10.1130/G23641A.1

Borchers, B., S. Marrero, G. Balco, M. Caffee, B. Goehring, N. Lifton, K. Nishiizumi, F. Phillips, J. Schaefer, and J. Stone (2016). Geological calibration of spallation production rates in the CRONUS- 
Earth project. $\quad$ Quaternary $\quad$ Geochronology, $\quad 31, \quad$ 188-198. https://doi.org/10.1016/j.quageo.2015.01.009

Braucher, R., S. Merchel, J. Borgomano, and D. Bourlès (2011). Production of cosmogenic radionuclides at great depth: A multi element approach. Earth and Planetary Science Letters, 309(1), 1-9. https://doi.org/10.1016/j.eps1.2011.06.036

Braucher, R., et al. (2013). Determination of muon attenuation lengths in depth profiles from in situ produced cosmogenic nuclides. Nuclear Instruments and Methods in Physics Research Section B: Beam Interactions with Materials and Atoms, 294, 484-490. https://doi.org/10.1016/j.nimb.2012.05.023

Brown, E. T., J. M. Edmond, G. M. Raisbeck, F. Yiou, M. D. Kurz, and E. J. Brook (1991). Examination of surface exposure ages of Antarctic moraines using in situ produced $10 \mathrm{Be}$ and $26 \mathrm{Al}$. Geochimica et Cosmochimica Acta, 55(8), 2269-2283.

Brown, E. T., R. F. Stallard, M. C. Larsen, G. M. Raisbeck, and F. Yiou (1995). Denudation rates determined from the accumulation of in situ-produced $10 \mathrm{Be}$ in the luquillo experimental forest, Puerto Rico. Earth and Planetary Science Letters, 129(1), 193-202. https://doi.org/10.1016/0012821X(94)00249-X

Burchfiel, B., C. Zhiliang, L. Yupinc, and L. Royden (1995). Tectonics of the Longmen Shan and adjacent regions, central China. International Geology Review, 37(8), 661-735. https://doi.org/10.1080/00206819509465424

Burchfiel, B., L. Royden, R. van der Hilst, B. Hager, Z. Chen, R. King, C. Li, J. Lü, H. Yao, and E. Kirby (2008). A geological and geophysical context for the Wenchuan earthquake of 12 May 2008, Sichuan, People's Republic of China. GSA Today, 18(7), 4-11. DOI: 10.1130/GSATG18A.1

Champagnac, J.-D., Molnar, P., Sue, C., \& Herman, F. (2012). Tectonics, climate, and mountain topography. Journal of Geophysical Research, 117(B2), B02403. https://doi.org/10.1029/2011JB008348

Chengdu Institute of Geology and Mineral Resources (2004), Geological map of the Qinghai - Xizang (Tibet) Plateau and adjacent areas, map, Geological, Beijing.

Clark, M. K., and L. H. Royden (2000). Topographic ooze: Building the eastern margin of Tibet by lower crustal flow. Geology, 28(8), 703-706. https://doi.org/10.1130/00917613(2000)28<703:TOBTEM>2.0.CO;2

Clark, M. K., J. W. Bush, and L. H. Royden (2005). Dynamic topography produced by lower crustal flow against rheological strength heterogeneities bordering the Tibetan Plateau. Geophysical Journal International, 162(2), 575-590. https://doi.org/10.1111/j.1365-246X.2005.02580.x

Cook, K. L., and L. H. Royden (2008). The role of crustal strength variations in shaping orogenic plateaus, with application to Tibet. Journal of Geophysical Research: Solid Earth, 113(B8). doi:10.1029/2007JB005457

Cook, K., L. Royden, B. Burchfiel, Y.-H. Lee, and X. Tan (2013). Constraints on Cenozoic tectonics in the southwestern Longmen Shan from low-temperature thermochronology. Lithosphere, 5(4), 393406. https://doi.org/10.1130/L263.1

Densmore, A. L., M. A. Ellis, Y. Li, R. Zhou, G. S. Hancock, and N. Richardson (2007). Active tectonics of the Beichuan and Pengguan faults at the eastern margin of the Tibetan Plateau. Tectonics, 26, TC4005. https://doi.org/10.1029/2006TC001987

DiBiase, R. A., K. X. Whipple, A. M. Heimsath, and W. B. Ouimet (2010). Landscape form and millennial erosion rates in the San Gabriel Mountains, CA. Earth and Planetary Science Letters, 
289(1), 134-144. https://doi.org/10.1016/j.epsl.2009.10.036

Dunne, J., D. Elmore, and P. Muzikar (1999). Scaling factors for the rates of production of cosmogenic nuclides for geometric shielding and attenuation at depth on sloped surfaces. Geomorphology, 27(1), 3-11. https://doi.org/10.1016/S0169-555X(98)00086-5

Farley, K. A. (2002). (U-Th)/He dating: Techniques, calibrations, and applications, noble gases in geochemistry and cosmochemistry. Reviews in Mineralogy and Geochemistry, 47, 819-843 pp. Mineralogical Society of America, Washington, DC. http://dx.doi.org/10.2138/rmg.2002.47.18

Fick, S. E., and R. J. Hijmans (2017). WorldClim 2: new 1-km spatial resolution climate surfaces for global land areas. International Journal of Climatology, 37(2), 5302-4315. https://doi.org/10.1002/joc.5086

Gallen, S. F., M. K. Clark, and J. W. Godt (2015). Coseismic landslides reveal near-surface rock strength in a high-relief, tectonically active setting. Geology, 43(1), 11-14. https://doi.org/10.1130/G36080.1

Godard, V., J. Lavé, J. Carcaillet, R. Cattin, D. Bourlès, and J. Zhu (2010). Spatial distribution of denudation in Eastern Tibet and regressive erosion of plateau margins. Tectonophysics, 491(1-4), 253274. https://doi.org/10.1016/j.tecto.2009.10.026

Godard, V., R. Pik, J. Lavé, R. Cattin, B. Tibari, J. De Sigoyer, M. Pubellier, and J. Zhu (2009). Late Cenozoic evolution of the central Longmen Shan, eastern Tibet: insight from (U-Th)/He thermochronometry. Tectonics, 28(5), TC5009. https://doi.org/10.1029/2008TC002407

Godard, V., D. L. Bourlès, F. Spinabella, D. W. Burbank, B. Bookhagen, G. B. Fisher, A. Moulin, and L. Léanni (2014). Dominance of tectonics over climate in Himalayan denudation. Geology, 42(3), 243-246. https://doi.org/10.1130/G35342.1

Granger, D. E., and A. L. Smith (2000). Dating buried sediments using radioactive decay and muogenic production of 26Al and 10Be. Nuclear Instruments and Methods in Physics Research B, 172, 822826. https://doi.org/10.1016/S0168-583X(00)00087-2

Granger, D. E., J. W. Kirchner, and R. Finkel (1996). Spatially averaged long-term erosion rates measured from in situ-produced cosmogenic nuclides in alluvial sediment. The Journal of Geology, 104, 249-257. https://www.jstor.org/stable/30068190

Gyssels, G., J. Poesen, E. Bochet, and Y. Li (2005). Impact of plant roots on the resistance of soils to erosion by water: a review. Progress in physical geography, 29(2), 189-217. https://doi.org/10.1191/0309133305pp443ra

Hetzel, R. (2013). Active faulting, mountain growth, and erosion at the margins of the Tibetan Plateau constrained by in situ-produced cosmogenic nuclides. Tectonophysics, 582, 1-24. https://doi.org/10.1016/j.tecto.2012.10.027

Hubbard, J., and J. H. Shaw (2009). Uplift of the Longmen Shan and Tibetan plateau, and the 2008 Wenchuan (M=7.9) earthquake. Nature, 458(7235), 194-197. https://doi.org/10.1038/nature07837

Hubbard, J., J. H. Shaw, and Y. Klinger (2010). Structural setting of the $2008 \mathrm{Mw} 7.9$ Wenchuan, China, earthquake. Bulletin of the Seismological Society of America, 100(5B), 2713-2735. DOI: $10.1785 / 0120090341$

Jia, D., Y. Li, A. Lin, M. Wang, W. Chen, X. Wu, Z. Ren, Y. Zhao, and L. Luo (2010). Structural model of 2008 Mw7.9 Wenchuan earthquake in the rejuvenated Longmen Shan thrust belt, China. Tectonophysics, 491(1), 174-184. https://doi.org/10.1016/S1876-3804(14)60070-7

Jin, W., L. Tang, K. Yang, G. Wan, and Z. Lü (2010). Segmentation of the Longmen Mountains thrust belt, Western Sichuan Foreland Basin, SW China. Tectonophysics, 485(1), 107-121. 
https://doi.org/10.1016/j.tecto.2009.12.007

Ketcham, R. A., R. A. Donelick, and W. D. Carlson (1999). Variability of apatite fission-track annealing kinetics: III. Extrapolation to geological time scales. American Mineralogist, 84(9), 1235-1255. https://doi.org/10.2138/am-1999-0903

King, R. W., F. Shen, B. C. Burchfiel, L. H. Royden, E. Wang, Z. Chen, Y. Liu, X.-Y. Zhang, J.-X. Zhao, and Y. Li (1997). Geodetic measurement of crustal motion in southwest China. Geology, 25(2), 179182. https://doi.org/10.1130/0091-7613(1997)025<0179:GMOCMI >2.3.CO;2

Kirby, E., and W. Ouimet (2011). Tectonic geomorphology along the eastern margin of Tibet: Insights into the pattern and processes of active deformation adjacent to the Sichuan Basin. Geological Society, London, Special Publications, 353(1), 165-188. https://doi.org/10.1144/SP353.9

Kirby, E., and K. X. Whipple (2012). Expression of active tectonics in erosional landscapes. Journal of Structural Geology, 44, 54-75. https://doi.org/10.1016/j.jsg.2012.07.009

Kirby, E., P. W. Reiners, M. A. Krol, K. X. Whipple, K. V. Hodges, K. A. Farley, W. Tang, and Z. Chen (2002). Late Cenozoic evolution of the eastern margin of the Tibetan Plateau: Inferences from 40Ar/39Ar and (U-Th)/He thermochronology. Tectonics, 21(1), 1-20. https://doi.org/10.1029/2000TC001246

Kirchner, J. W., R. C. Finkel, C. S. Riebe, D. E. Granger, J. L. Clayton, J. G. King, and W. F. Megahan (2001). Mountain erosion over $10 \mathrm{yr}, 10 \mathrm{ky}$, and $10 \mathrm{my}$ time scales. Geology, 29(7), 591-594. https://doi.org/10.1130/0091-7613(2001)029<0591:MEOYKY>2.0.CO;2Kirkpatrick, H. M., S. Moon, A. Yin, and T. M. Harrison (2021). Impact of fault damage on eastern Tibet topography. Geology, 49(1), 30-34. https://doi.org/10.1130/G48179.1

Korup, O., and J. T. Weidinger (2011). Rock type, precipitation, and the steepness of Himalayan threshold hillslopes. Geological Society, London, Special Publications, 353(1), 235-249. https://doi.org/10.1144/SP353.12

Lague, D., Hovius, N., \& Davy, P. (2005). Discharge, discharge variability, and the bedrock channel profile. Journal of Geophysical Research, 110(F4), F04006. https://doi.org/10.1029/2004JF000259

Lal, D. (1991). Cosmic ray labeling of erosion surfaces: in situ nuclide production rates and erosion models. Earth and Planetary Science Letters, 104(2-4), 424-439. https://doi.org/10.1016/0012821X(91)90220-C

Larsen, I. J., and D. R. Montgomery (2012). Landslide erosion coupled to tectonics and river incision. Nature Geoscience, 5(7), 468-473. https://doi.org/10.1038/ngeo1479

Li, Z., J. Liu-Zeng, R. Almeida, J. Hubbard, C. Sun, and G. Yi (2017). Re-evaluating seismic hazard along the southern Longmen Shan, China: Insights from the 1970 Dayi and 2013 Lushan earthquakes. Tectonophysics, 717, 519-530. https://doi.org/10.1016/j.tecto.2017.09.001

Liu-Zeng, J., L. Wen, M. Oskin, and L. Zeng (2011). Focused modern denudation of the Longmen Shan margin, eastern Tibetan Plateau. Geochemistry Geophysics Geosystems, 12(11), Q11007. https://doi.org/10.1029/2011GC003652

Liu-Zeng, J., Z. Zhang, L. Wen, P. Tapponnier, J. Sun, X. Xing, G. Hu, Q. Xu, L. Zeng, and L. Ding (2009). Co-seismic ruptures of the 12 May 2008,Ms 8.0 Wenchuan earthquake, Sichuan: East-west crustal shortening on oblique, parallel thrusts along the eastern edge of Tibet. Earth and Planetary Science Letters, 286(3), 355-370. https://doi.org/10.1016/j.epsl.2009.07.017

Mandal, S. K., M. Lupker, J.-P. Burg, P. G. Valla, N. Haghipour, and M. Christl (2015). Spatial variability of 10Be-derived erosion rates across the southern Peninsular Indian escarpment: A key to landscape evolution across passive margins. Earth and Planetary Science Letters, 425, 154-167. 
https://doi.org/10.1016/j.epsl.2015.05.050

Molnar, P., and P. England (1990). Late Cenozoic uplift of mountain ranges and global climate change: chicken or egg? Nature, 346(6279), 29-34. https://doi.org/10.1038/346029a0

Montgomery, D. R., and K. B. Gran (2001). Downstream variations in the width of bedrock channels. Water Resources Research, 37(6), 1841-1846. https://doi.org/10.1029/2000WR900393

Montgomery, D. R., and M. T. Brandon (2002). Topographic controls on erosion rates in tectonically active mountain ranges. Earth and Planetary Science Letters, 201(3), 481-489. https://doi.org/10.1016/S0012-821X(02)00725-2

Moosdorf, N., S. Cohen, and C. von Hagke (2018). A global erodibility index to represent sediment production potential of different rock types. Applied Geography, 101, 36-44. https://doi.org/10.1016/j.apgeog.2018.10.010

Niemi, N. A., M. Oskin, D. W. Burbank, A. M. Heimsath, and E. J. Gabet (2005). Effects of bedrock landslides on cosmogenically determined erosion rates. Earth and Planetary Science Letters, 237(3), 480-498. https://doi.org/10.1016/j.epsl.2005.07.009

Nishiizumi, K., M. Imamura, M. W. Caffee, J. R. Southon, R. C. Finkel, and J. McAninch (2007). Absolute calibration of ${ }^{10} \mathrm{Be}$ AMS standards. Nuclear Instruments and Methods in Physics Research Section B: Beam Interactions with Materials and Atoms, 258(2), 403-413. https://doi.org/10.1016/j.nimb.2007.01.297

Olen, S. M., B. Bookhagen, and M. R. Strecker (2016). Role of climate and vegetation density in modulating denudation rates in the Himalaya. Earth and Planetary Science Letters, 445, 57-67. https://doi.org/10.1016/j.eps1.2016.03.047

Ouimet, W. B. (2010). Landslides associated with the May 12, 2008 Wenchuan earthquake: Implications for the erosion and tectonic evolution of the Longmen Shan. Tectonophysics, 491(1-4), 244-252. https://doi.org/10.1016/j.tecto.2009.09.012

Ouimet, W. B., K. X. Whipple, and D. E. Granger (2009). Beyond threshold hillslopes: Channel adjustment to base-level fall in tectonically active mountain ranges. Geology, 37(7), 579-582. https://doi.org/10.1130/G30013A.1

Kirby, E., and W. Ouimet (2011). Tectonic geomorphology along the eastern margin of Tibet: Insights into the pattern and processes of active deformation adjacent to the Sichuan Basin. Geological Society, London, Special Publications, 353(1), 165-188. https://doi.org/10.1144/SP353.9

Phillips, F. M., M. Hinz, S. M. Marrero, and K. Nishiizumi (2016). Cosmogenic nuclide data sets from the Sierra Nevada, California, for assessment of nuclide production models: II. Sample sites and evaluation. Quaternary Geochronology, 35, 101-118. https://doi.org/10.1016/j.quageo.2016.01.003

Ran, Y., L. Chen, J. Chen, H. Wang, G. Chen, J. Yin, X. Shi, C. Li, and X. Xu (2010). Paleoseismic evidence and repeat time of large earthquakes at three sites along the Longmenshan fault zone. Tectonophysics, 491(1), 141-153. https://doi.org/10.1016/j.tecto.2010.01.009

Reiners, P. W., and M. T. Brandon (2006). Using thermochronology to understand orogenic erosion. Annu. Rev. Earth Planet. Sci., 34, 419-466. DOI: 10.1146/annurev.earth.34.031405.125202

Richardson, N. J., A. L. Densmore, D. Seward, A. Fowler, M. Wipf, M. A. Ellis, L. Yong, and Y. Zhang (2008). Extraordinary denudation in the Sichuan Basin: Insights from low-temperature thermochronology adjacent to the eastern margin of the Tibetan Plateau. Journal of Geophysical Research-Solid Earth, 113, B04409. https://doi.org/10.1029/2006JB004739

Robert, A., M. Pubellier, J. De Sigoyer, J. Vergne, A. Lahfid, R. Cattin, N. Findling, and J. Zhu (2010). Structural and thermal characters of the Longmen Shan (Sichuan, China). Tectonophysics, 491(1), 
165-173. https://doi.org/10.1016/j.tecto.2010.03.018

Roering, J. J., J. W. Kirchner, and W. E. Dietrich (2001). Hillslope evolution by nonlinear, slopedependent transport: Steady state morphology and equilibrium adjustment timescales. Journal of Geophysical Research: Solid Earth, 106(B8), 16499-16513. https://doi.org/10.1029/2001JB000323

Rossi, M. W., K. X. Whipple, and E. R. Vivoni (2016). Precipitation and evapotranspiration controls on daily runoff variability in the contiguous United States and Puerto Rico. Journal of Geophysical Research: Earth Surface, 121(1), 128-145. https://doi.org/10.1002/2015JF003446

Royden, L. H., B. C. Burchfiel, R. W. King, E. Wang, Z. Chen, F. Shen, and Y. Liu (1997). Surface deformation and lower crustal flow in eastern Tibet. Science, 276(5313), 788-790. DOI: $10.1126 /$ science. 276.5313 .788

Scherler, D., B. Bookhagen, and M. R. Strecker (2014). Tectonic control on 10Be-derived erosion rates in the Garhwal Himalaya, India. Journal of Geophysical Research: Earth Surface, 119(2), 83-105. https://doi.org/10.1002/2013JF002955

Scherler, D., R. A. DiBiase, G. B. Fisher, and J.-P. Avouac (2017). Testing monsoonal controls on bedrock river incision in the Himalaya and Eastern Tibet with a stochastic-threshold stream power model. Journal of Geophysical Research: Earth Surface, 122(7), 1389-1429. https://doi.org/10.1002/2016JF004011

Schide, K., S. Gallen, M. Lupker, L. Märki, N. Haghipour, M. Christl, and S. Willett (2019). Using Cosmogenic Nuclides to Evaluate the Role of Coseismic Landsliding on Measured Erosion Rates Following the Mw 7.8 Gorkha Earthquake, Nepal. EGUGA, 15609.

Schmidt, K. M., and D. R. Montgomery (1995). Limits to relief. Science, 270(5236), 617-620. DOI: $10.1126 /$ science. 270.5236 .617

Schmidt, A. H., V. S. Gonzalez, P. R. Bierman, T. B. Neilson, and D. H. Rood (2018). Agricultural land use doubled sediment loads in western China's rivers. Anthropocene, 21, 95-106. https://doi.org/10.1016/j.ancene.2017.10.002

Schwanghart, W., and D. Scherler (2014). Short Communication: TopoToolbox 2 - MATLAB-based software for topographic analysis and modeling in Earth surface sciences. Earth Surface Dynamics, 2(1), 1-7. https://doi.org/10.5194/esurf-2-1-2014

Shen, X., Y. Tian, G. Zhang, S. Zhang, A. Carter, B. Kohn, P. Vermeesch, R. Liu, and W. Li (2019). Late Miocene hinterland crustal shortening in the Longmen Shan thrust belt, the eastern margin of the Tibetan Plateau. Journal of Geophysical Research: Solid Earth, 124, 11972-11991. https://doi.org/10.1029/2019JB018358

Sklar, L., and W. E. Dietrich (1998). River Longitudinal Profiles and Bedrock Incision Models: Stream Power and the Influence of Sediment Supply, 538-541 pp. American Geophysical Union. https://doi.org/10.1029/GM107p0237

Stone, J. O. (2000). Air pressure and cosmogenic isotope production. Journal of geophysical research, 105(B10), 23753-23723,23759. https://doi.org/10.1029/2000JB900181

Suppe, J. (1983). Geometrv and Kinematics of Fault-bend Folding. American Journal of Science, 283, 6841. DOI: $10.2475 /$ ajs.283.7.684

Tan, X.-B., Y.-H. Lee, W.-Y. Chen, K. L. Cook, and X.-W. Xu (2014). Exhumation history and faulting activity of the southern segment of the Longmen Shan, eastern Tibet. Journal of Asian Earth Sciences, 81, 91-104. https://doi.org/10.1016/j.jseaes.2013.12.002

Tan, X.-B., X.-W. Xu, Y.-H. Lee, R.-Q. Lu, Y. LIu, C. Xu, K. Li, G.-H. Yu, and W.-J. Kang (2017). Late Cenozoic thrusting of major faults along the central segment of Longmen Shan, eastern Tibet: 
Evidence from low-temperature thermochronology. Tectonophysics, 712-713, 145-155. https://doi.org/10.1016/j.tecto.2017.05.016

Tan, X., Y. Liu, Y.-H. Lee, R. Lu, X. Xu, J. Suppe, F. Shi, and C. Xu (2019). Parallelism between the maximum exhumation belt and the Moho ramp along the eastern Tibetan Plateau margin: Coincidence or consequence? Earth and Planetary Science Letters, 507, 73-84. https://doi.org/10.1016/j.epsl.2018.12.001

Tang, C., G. Ma, M. Chang, W. Li, D. Zhang, T. Jia, and Z. Zhou (2015). Landslides triggered by the 20 April 2013 Lushan earthquake, Sichuan Province, China : A case study in a region near the epicenter. Engineering Geology, 187, 45-55.https://doi.org/10.1016/j.enggeo.2014.12.004

Tapponnier, P., X. Zhiqin, F. Roger, B. Meyer, N. Arnaud, G. Wittlinger, and Y. Jingsui (2001). Oblique Stepwise Rise and Growth of the Tibetan Plateau. Science, 294(5547), 1671-1677. DOI: 10.1126/science. 105978

Tian, Y., B. P. Kohn, A. J. W. Gleadow, and S. Hu (2013). Constructing the Longmen Shan eastern Tibetan Plateau margin: Insights from low-temperature thermochronology. Tectonics, 32(3), 576-592. https://doi.org/10.1002/tect.20043

Tian, Y., B. P. Kohn, S. Hu, and A. J. Gleadow (2015). Synchronous fluvial response to surface uplift in the eastern Tibetan Plateau: Implications for crustal dynamics. Geophysical Research Letters, 42(1), 29-35. https://doi.org/10.1002/2014GL062383

Tucker, G. E., and G. R. Hancock (2010). Modelling landscape evolution. Earth Surface Processes and Landforms, 35(1), 28-50. DOI: 10.1002/esp.1952

Wang, E., E. Kirby, K. P. Furlong, M. van Soest, G. Xu, X. Shi, P. J. Kamp, and K. Hodges (2012). Two-phase growth of high topography in eastern Tibet during the Cenozoic. Nature Geoscience, 5(9), 640-645. https://doi.org/10.1038/ngeo1538

Wang, H., L. Chen, Y. Ran, S. Lei, and X. Li (2015). Paleoseismic investigation of the seismic gap between the seismogenic structures of the 2008 Wenchuan and 2013 Lushan earthquakes along the Longmen Shan fault zone at the eastern margin of the Tibetan Plateau. Lithosphere, 7(1), 14-20. https://doi.org/10.1130/L373.1

Wang, H., H. B. Li, L. Zhang, Y. Zheng, J. L. Si, and Z. M. Sun (2019). Paleoseismic Slip Records and Uplift of the Longmen Shan, Eastern Tibetan Plateau. Tectonics, 38(1), 354-373. https://doi.org/10.1029/2018TC005278

Wang, M., D. Jia, J. H. Shaw, J. Hubbard, A. Plesch, Y. Li, and B. Liu (2014). The 2013 Lushan earthquake: Implications for seismic hazards posed by the Range Front blind thrust in the Sichuan Basin, China. Geology, 42(10), 915-918. https://doi.org/10.1130/G35809.1

Wang, W., et al. (2017). Perturbation of fluvial sediment fluxes following the 2008 Wenchuan earthquake. Earth Surface Processes and Landforms, 42(15), 2611-2622. https://doi.org/10.1002/esp.4210

West, A. J., R. Hetzel, G. Li, Z. Jin, F. Zhang, R. G. Hilton, and A. L. Densmore (2014). Dilution of $10 \mathrm{Be}$ in detrital quartz by earthquake-induced landslides: Implications for determining denudation rates and potential to provide insights into landslide sediment dynamics. Earth and Planetary Science Letters, 396, 143-153. https://doi.org/10.1016/j.epsl.2014.03.058

Whipple, K. X., and G. E. Tucker (1999). Dynamics of the stream-power river incision model: Implications for height limits of mountain ranges, landscape response timescales, and research needs. Journal of Geophysical Research: Solid Earth, 104(B8), 17661-17674. https://doi.org/10.1029/1999JB900120 
Willett, S. D. (1999). Orogeny and orography: The effects of erosion on the structure of mountain belts. Journal of Geophysical Research, 104(B12), 28957. https://doi.org/10.1029/1999JB900248

Willett, S. D., and M. T. Brandon (2002). On steady states in mountain belts. Geology, 30(2), 175-178. doi: 10.1130/0091-7613(2002)030<0175:OSSIMB $>2.0 . C O ; 2$

Willett, S. D., and M. T. Brandon (2013). Some analytical methods for converting thermochronometric age to erosion rate. Geochemistry, Geophysics, Geosystems, 14(1), 209-222. https://doi.org/10.1029/1999JB900120

Wilson, C. J., and A. P. Fowler (2011). Denudational response to surface uplift in east Tibet: Evidence from apatite fission-track thermochronology. Geological Society of America Bulletin, 123(9-10), 1966-1987. https://doi.org/10.1130/B30331.1

Xu, C., X. Xu, X. Yao, and F. Dai (2014). Three (nearly) complete inventories of landslides triggered by the May 12, 2008 Wenchuan Mw 7.9 earthquake of China and their spatial distribution statistical analysis. Landslides, 11(3), 441-461. https://doi.org/10.1007/s10346-013-0404-6

Xu, G., and P. J. J. Kamp (2000). Tectonics and denudation adjacent to the Xianshuihe Fault, eastern Tibetan Plateau: Constraints from fission track thermochronology. Journal of Geophysical Research Atmospheres, 105(B8), 19231-19252. https://doi.org/10.1029/2000JB900159

Xu, X., X. Wen, G. Yu, G. Chen, Y. Klinger, J. Hubbard, and J. Shaw (2009). Coseismic reverse-and oblique-slip surface faulting generated by the $2008 \mathrm{Mw} 7.9$ Wenchuan earthquake, China. Geology, 37(6), 515-518. https://doi.org/10.1130/G25462A.1

Xu, X., X. Wen, and Z. Han (2013). Lushan Ms 7.0 earthquake: a blind reserve-fault event. Chin Sci Bull, 58(28-29), 3437-3443. https://doi.org/10.1007/s11434-013-5999-4

Xu, X., Z. Han, X. Yang, S. Zhang, G. Yu, B. Zhou, F. Li, B. Ma, G. Chen, and Y. Ran (2016), Seismic structure map of China and its adjacent areas, Seismological Press (in Chinese), Beijing.

Yan, D.-P., M.-F. Zhou, H.-L. Song, X.-W. Wang, and J. Malpas (2003). Origin and tectonic significance of a Mesozoic multi-layer over-thrust system within the Yangtze Block (South China). Tectonophysics, 361(3-4), 239-254. https://doi.org/10.1016/S0040-1951(02)00646-7

Yi, G.-X., X.-Z. Wen, H. Xin, H.-Z. Qiao, F. Long, and S.-W. Wang (2011). Distributions of seismicity parameters and seismic apparent stresses on the Longmenshan-Minshan tectonic zone before the 2008 MS 8. 0 Wenchuan earthquake. Chinese J. Geophys, 54(6), 1490-1500. (in Chinese)

Zhang, H., P. Zhang, E. Kirby, J. Yin, C. Liu, and G. Yu (2011). Along-strike topographic variation of the Longmen Shan and its significance for landscape evolution along the eastern Tibetan Plateau. Journal of Asian Earth Sciences, 40(4), 855-864. https://doi.org/10.1016/j.jseaes.2010.05.015

Zhang, P.-Z. (2013). A review on active tectonics and deep crustal processes of the Western Sichuan region, eastern margin of the Tibetan Plateau. Tectonophysics, 584, 7-22. https://doi.org/10.1016/j.tecto.2012.02.021

Zhang, P. Z., Z. Shen, M. Wang, W. Gan, R. Bürgmann, P. Molnar, Q. Wang, Z. Niu, J. Sun, and J. Wu (2004). Continuous deformation of the Tibetan Plateau from global positioning system data. Geology, 32(9), 809-812. http://doi.org/10.1130/G20554.1

Zhou, R. J., Y. Li, A. L. Densmore, M. A. Ellis, Y. L. He, Y. Z. Li, and Y. G. Li (2007). Active Tectonics of the Longmen Shan Region on the Eastern Margin of the Tibetan Plateau. Acta Geologica Sinica, 81(4), 593-604. (in Chinese) 
Figure 1. Structural map of the eastern Tibetan margin (modified from Chengdu Institute of Geology and Mineral Resources [2004]; Xu et al. [2016]). Black dashed rectangle denotes the area of Figure 2, and white dashed rectangle indicates the location of swath profiles used in Figures 7-8. Red lines show the location of the surface rupture of the 2008 Wenchuan earthquake modified from Liu-Zeng et al. (2009). GDF: Genda fault; YJF: Yanjin fault; DCF: Dachuan fault; RFBT: Range Front Blind Thrust, modified from Li et al. (2017); WMF: Wenchuan fault; YBF: Beichuan fault; PGR: Pengguan fault; QXF: Qiongxi fault; DYF: Dayi fault; XPF: Xiongpo fault; PZF: Pengzhou fault; LQF: Longquan fault; MJF: Minjiang fault; HYF: Huya fault; QCF: Qingchuan fault; MRGF: Maoergai fault; LRBF: Longriba fault. In the legend, EI represents the rock erodibility index, proposed by Moosdorf et al. (2018). A high EI value indicates both high sensitivity to weathering and low compressive strength.

Figure 2. Hillshade map showing sample locations, studied catchments, and denudation rates calculated from ${ }^{10} \mathrm{Be}$ concentrations. The data corresponding to sample IDs are given in Table 2.

Fig 3. Morphometric, lithological, and climatic parameters along the eastern Tibetan margin. (a) Hillslope gradient; (b) 1-km radius relief; (c) normalized channel steepness index, $k_{s n}$; (d) annual rainfall, based on a 30-yr averaged climatic data (Fick \& Hijmans, 2017); (e) specific stream power, SSP, calculated using a scaling relationship between width and discharge of $\mathrm{W}=10 \mathrm{Q}_{\mathrm{w}}{ }^{0.5}$ (Montgomery \& Gran, 2001; Tucker \& Hancock, 2010); (f) rock erodibility index, EI (Moosdorf et al., 2018); (g) 7-yr average of normalized difference vegetation index, NDVI; and (h) 7-yr average of seasonality index of NDVI, SI, resulting from the division of summer NDVI by winter NDVI.

Fig 4. Comparison between denudation rates and catchment morphometric, lithological, and climatic parameters. Red circles are samples from this study. Green circles are samples from the central Longmen Shan (Godard et al., 2010). Gray and white circles represent samples from the Minjiang and Dadu rivers, respectively (Ouimet et al., 2009; 
Godard et al., 2010; Ansberque et al., 2015). The best fits in all figures just apply to

${ }^{10} \mathrm{Be}$ results from this study, collected in the southern Longmen Shan. (a) Mean catchment slope gradient. Solid line represents the nonlinear hillslope erosion model of Roering et al. (2001), calculated with $\mathrm{L}_{\mathrm{H}}$ (characteristic hillslope length) $=75 \mathrm{~m}$ and $\mathrm{K}$ (diffusion coefficient) $=0.018 \mathrm{~m}^{2} / \mathrm{y}$. (b) Mean catchment $1-\mathrm{km}$ radius relief. (c) Normalized channel steepness index, $k_{s n}$, with two possible fits to our data. Solid line is a linear model, and dashed line is a power law model with an exponent of 1.8. (d) Mean catchment precipitation. (e) Mean catchment specific stream power. (f) Mean catchment rock erodibility index. (g) Mean catchment NDVI. (h) Mean catchment SI.

Figure 5. Denudation rates derived from ${ }^{10} \mathrm{Be}$ concentration when considering or not the heterogeneities in quartz content from different rock types. The calculated denudation rates are highly similar, suggesting that within the resolution of the data, the influence of lithology on denudation rate estimates is negligible.

Figure 6. Relationship between normalized channel steepness index $\left(k_{s n}\right)$ and denudation rates, and grey lines show two modeling curves based on the channel incision model. For a given channel steepness, weaker rocks and/or wetter, stormier climates are expected to correspond to a higher denudation rate according to channel incision model (Whipple \& Tucker, 1999). Neither previous ${ }^{10} \mathrm{Be}$-derived denudation rates from Minjiang, Dadu, and central Longmen Shan, nor our results from southern Longmen Shan show clear indication that (a) rock erodibility; (b) precipitation; (c) normalized difference vegetation index, NDVI; or (d) seasonality of vegetation density, SI, alone can explain the scatter in the functional relationship between $k_{s n}$ and denudation rates in Eastern Tibet.

Figure 7. Swath profile $(50 \mathrm{~km}$ width) showing the distribution of topographic parameters and denudation rates across the southern and central Longmen Shan (see Figure 1 for location). (a) and (f) Mean topographic profile derived from 30-m ASTER 
Global Elevation Maps (black line: mean elevation; grey line: maximum and minimum elevation) and basin-averaged denudation rates derived from ${ }^{10} \mathrm{Be}$ concentration (See Figure S1). Red circles refer to catchments located in the southern Longmen Shan from our study. Green circles denote previous studied catchments located in the central range (Godard et al., 2010). White and grey circles represent samples located along the Dadu River and Minjiang River, respectively (Ansberque et al., 2015; Godard et al., 2010; Ouimet et al., 2009; Figure S1). Error bars on denudation rates are $\pm 1 \sigma$. Error bars on distance correspond to the limits of projected catchment extent along the profile. (b) Hillslope angles frequency profile. Circles are average hillslope gradient over the catchments with ${ }^{10} \mathrm{Be}$ data. (c) Distribution of catchment-averaged channel steepness $\left(k_{s n}\right)$ for catchments with ${ }^{10} \mathrm{Be}$ data, and third- and fourth- order basins along the swath profile. (d) Projection of exhumation rates derived from apatite $\mathrm{U}-\mathrm{Th} / \mathrm{He}(\mathrm{AHe})$ and fission-track (AFT) dating (Arne et al., 1997; Ansberque et al., 2018; Cook et al., 2013; Godard et al., 2009; Kirby et al., 2002; Richardson et al., 2008; Shen et al., 2019; Tian et al., 2013; 2015; Wang et al., 2012; Wilson \& Fowler, 2011; Xu \& Kamp, 2000). (e) Projection of Zircon U-Th/He (ZHe) and fission-track (ZFT) data (Ansberque et al., 2018; Cook et al., 2013; Godard et al., 2009; Kirby et al., 2002; Shen et al., 2019; Tian et al., 2013; Xu \& Kamp, 2000).

Figure 8. Denudation rates and fault geometry underneath the surface across the southern and central Longmen Shan margin. The box plots of denudation rate are derived from ${ }^{10} \mathrm{Be}$ concentration (red color) and apatite low-temperature thermochronology (light green color) shown in Figure 7. Regional cross-sections are derived from the compilation of deep and shallow interpreted seismic reflection data and structural observations (Hubbard \& Shaw, 2009; Jia et al., 2010; Li et al., 2017). Shaded areas denote the high exhumation/denudation zones. 
Table 1. Catchment characteristics

\begin{tabular}{|c|c|c|c|c|c|c|c|c|c|c|}
\hline ID & $\begin{array}{l}\text { Area } \\
\left(\mathrm{km}^{2}\right)\end{array}$ & $\begin{array}{l}\text { Mean } \\
\text { Elevation } \\
(\mathrm{m})\end{array}$ & $\begin{array}{l}\text { Mean } \\
\text { slope } \\
\left(^{\circ}\right)\end{array}$ & $\begin{array}{l}\text { Mean } \\
\text { relief }^{a} \\
(\mathrm{~m})\end{array}$ & $\begin{array}{c}\text { Mean } \\
k_{s n} \mathrm{~b} \\
\left(\mathrm{~m}^{0.8}\right)\end{array}$ & $\begin{array}{l}\text { Mean } \\
\text { rainfall } \\
\left(\mathrm{mm} \mathrm{y}^{-1}\right)\end{array}$ & $\begin{array}{c}\text { Mean } \\
\mathrm{SSP}^{\mathrm{c}} \\
\left(\mathrm{W} \cdot \mathrm{m}^{-2}\right)\end{array}$ & Mean $\mathrm{EI}^{\mathrm{d}}$ & $\begin{array}{l}\text { Mean } \\
\text { NDVI }^{\mathrm{e}}\end{array}$ & Mean $\mathrm{SI}^{\mathrm{f}}$ \\
\hline 01 & 150 & 1521 & 18 & 466 & $72 \pm 75$ & 1115 & 27 & 1.24 & $0.52 \pm 0.07$ & $1.37 \pm 0.09$ \\
\hline 02 & 18 & 1424 & 18 & 431 & $49 \pm 33$ & 1130 & 19 & 1.34 & $0.54 \pm 0.03$ & $1.28 \pm 0.05$ \\
\hline 03 & 66 & 1876 & 26 & 723 & $161 \pm 71$ & 1014 & 56 & 1.04 & $0.44 \pm 0.07$ & $1.32 \pm 0.17$ \\
\hline 04 & 173 & 2256 & 31 & 904 & $188 \pm 37$ & 917 & 69 & 1.00 & $0.44 \pm 0.08$ & $1.15 \pm 0.17$ \\
\hline 05 & 176 & 1838 & 25 & 706 & $146 \pm 68$ & 1023 & 52 & 1.13 & $0.46 \pm 0.07$ & $1.30 \pm 0.13$ \\
\hline 06 & 174 & 1138 & 15 & 361 & $61 \pm 61$ & 1283 & 23 & 1.46 & $0.53 \pm 0.04$ & $1.48 \pm 0.09$ \\
\hline 07 & 118 & 2282 & 24 & 730 & $124 \pm 74$ & 879 & 42 & 1.00 & $0.54 \pm 0.08$ & $1.18 \pm 0.20$ \\
\hline 08 & 63 & 1498 & 21 & 562 & $117 \pm 57$ & 1127 & 45 & 1.38 & $0.49 \pm 0.07$ & $1.46 \pm 0.08$ \\
\hline 09 & 243 & 932 & 17 & 416 & $58 \pm 40$ & 1304 & 24 & 1.50 & $0.55 \pm 0.04$ & $1.29 \pm 0.04$ \\
\hline 10 & 36 & 2162 & 32 & 931 & $176 \pm 48$ & 930 & 64 & 1.00 & $0.42 \pm 0.07$ & $1.05 \pm 0.17$ \\
\hline 11 & 91 & 1785 & 28 & 674 & $123 \pm 37$ & 999 & 46 & 1.00 & $0.58 \pm 0.04$ & $1.16 \pm 0.07$ \\
\hline 12 & 1233 & 3178 & 28 & 810 & $201 \pm 57$ & 786 & 72 & 1.24 & $0.50 \pm 0.14$ & $1.38 \pm 0.68$ \\
\hline 13 & 183 & 830 & 12 & 291 & $31 \pm 36$ & 1412 & 14 & 1.74 & $0.54 \pm 0.04$ & $1.31 \pm 0.04$ \\
\hline 14 & 403 & 3122 & 31 & 886 & $180 \pm 83$ & 829 & 67 & 1.05 & $0.42 \pm 0.13$ & $0.88 \pm 0.21$ \\
\hline 15 & 446 & 2452 & 32 & 913 & $203 \pm 62$ & 857 & 73 & 1.10 & $0.44 \pm 0.09$ & $1.17 \pm 0.18$ \\
\hline 16 & 98 & 1555 & 25 & 636 & $112 \pm 38$ & 1096 & 44 & 1.02 & $0.53 \pm 0.03$ & $1.42 \pm 0.13$ \\
\hline 17 & 1970 & 2284 & 29 & 817 & $174 \pm 68$ & 947 & 65 & 1.05 & $0.49 \pm 0.11$ & $1.15 \pm 0.27$ \\
\hline 18 & 2770 & 2969 & 28 & 840 & $189 \pm 80$ & 808 & 66 & 1.15 & $0.48 \pm 0.14$ & $1.23 \pm 0.37$ \\
\hline 19 & 69 & 1918 & 33 & 946 & $169 \pm 32$ & 975 & 63 & 1.00 & $0.42 \pm 0.07$ & $1.28 \pm 0.13$ \\
\hline 20 & 318 & 2306 & 28 & 767 & $160 \pm 46$ & 906 & 58 & 1.09 & $0.51 \pm 0.09$ & $1.13 \pm 0.17$ \\
\hline 21 & 622 & 2939 & 30 & 926 & $224 \pm 64$ & 840 & 81 & 1.00 & $0.44 \pm 0.14$ & $1.15 \pm 0.24$ \\
\hline 22 & 325 & 2269 & 31 & 880 & $182 \pm 51$ & 934 & 68 & 1.04 & $0.44 \pm 0.08$ & $1.26 \pm 0.22$ \\
\hline 23 & 164 & 1127 & 13 & 339 & $32 \pm 40$ & 1314 & 17 & 1.50 & $0.51 \pm 0.03$ & $1.36 \pm 0.07$ \\
\hline 24 & 326 & 1681 & 26 & 693 & $135 \pm 57$ & 1022 & 52 & 1.29 & $0.43 \pm 0.07$ & $1.29 \pm 0.13$ \\
\hline 25 & 131 & 1178 & 23 & 590 & $91 \pm 43$ & 1111 & 37 & 1.50 & $0.48 \pm 0.06$ & $1.27 \pm 0.06$ \\
\hline
\end{tabular}

${ }^{\mathrm{a}}$ Using a $1-\mathrm{km}$ radius window.

${ }^{\mathrm{b}}$ Normalized steepness index $\left(\theta_{\text {ref }}=0.4\right)$

${ }^{\mathrm{c}}$ Specific stream power calculated using a scaling relationship between width and discharge of $\mathrm{W}=$ $10 \mathrm{Q}_{\mathrm{w}}{ }^{0.5}$.

${ }^{\mathrm{d}}$ Rock erodibility index (Moosdorf et al., 2018).

e 7 -yr average of normalized difference vegetation index.

f 7-yr average of seasonality index resulting from the division of summer NDVI by winter NDVI. 
Table 2. ${ }^{10} \mathrm{Be}$ analytical and derived denudation rate.

\begin{tabular}{|c|c|c|c|c|c|c|c|c|c|c|c|c|}
\hline \multirow[b]{2}{*}{ ID } & \multirow[b]{2}{*}{ Sample } & \multirow[b]{2}{*}{$\begin{array}{l}\text { Latitude } \\
\left({ }^{\circ} \mathrm{N}\right)\end{array}$} & \multirow[b]{2}{*}{$\begin{array}{l}\text { Longitude } \\
\quad\left({ }^{\circ} \mathrm{E}\right)\end{array}$} & \multirow[b]{2}{*}{$\begin{array}{l}\operatorname{Mass}^{\mathrm{a}} \\
(\mathrm{g})\end{array}$} & \multirow[b]{2}{*}{$\begin{array}{c}{ }^{[10} \mathrm{Be}^{\mathrm{b}} \\
\left(10^{3} \text { atoms g }\right. \\
\end{array}$} & \multicolumn{4}{|c|}{ Without considering lithology ${ }^{\mathrm{c}}$} & \multicolumn{3}{|c|}{ Considering lithology ${ }^{\mathrm{d}}$} \\
\hline & & & & & & $\begin{array}{c}\text { Spallogenic } \\
\text { Production } \\
\text { rate }\left(\text { at } \mathrm{g} \mathrm{yr}^{-1}\right)^{\mathrm{e}}\end{array}$ & $\begin{array}{c}\text { Muogenic } \\
\text { Production } \\
\text { rate }(\text { at } \mathrm{g} \mathrm{yr} \\
\left.{ }^{1}\right)^{\mathrm{f}}\end{array}$ & $\begin{array}{l}\text { Denudation rateg } \\
\left(\mathrm{mm} \mathrm{yr}^{-1}\right)\end{array}$ & $\begin{array}{l}\text { Time-scale }^{\mathrm{h}} \\
\text { (yr) }\end{array}$ & Spallogenice & Muogenic ${ }^{f}$ & $\begin{array}{c}\text { Denudation } \\
\text { rate }^{\mathrm{g}}(\mathrm{mm} \\
\left.\mathrm{yr}^{-1}\right)\end{array}$ \\
\hline 01 & LS13-01W & 30.2427 & 102.9247 & 13 & $68.01 \pm 3.73$ & 11.07 & 0.05 & $0.11 \pm 0.01$ & 5491 & 10.41 & 0.05 & $0.10 \pm 0.01$ \\
\hline 02 & LS13-03W & 30.2938 & 102.9376 & 14 & $126.51 \pm 10.82$ & 9.61 & 0.04 & $0.05 \pm 0.01$ & 11680 & 9.09 & 0.04 & $0.05 \pm 0.01$ \\
\hline 03 & LS13-04W & 30.3413 & 102.9922 & 12 & $81.42 \pm 7.11$ & 13.20 & 0.05 & $0.11 \pm 0.01$ & 5557 & 15.78 & 0.06 & $0.13 \pm 0.02$ \\
\hline 04 & LS13-05 & 30.0737 & 102.6176 & 7 & $58.60 \pm 9.38$ & 16.49 & 0.06 & $0.19 \pm 0.04$ & 3229 & 14.05 & 0.05 & $0.16 \pm 0.03$ \\
\hline 05 & LS13-05W & 30.3252 & 102.9950 & 8 & $44.72 \pm 6.81$ & 12.88 & 0.05 & $0.19 \pm 0.03$ & 3125 & 13.99 & 0.05 & $0.21 \pm 0.04$ \\
\hline 06 & LS13-06W & 30.1076 & 102.8977 & 11 & $45.74 \pm 3.01$ & 8.03 & 0.04 & $0.12 \pm 0.01$ & 5022 & 7.22 & 0.04 & $0.11 \pm 0.01$ \\
\hline 07 & LS13-08 & 30.4193 & 102.7280 & 11 & $27.04 \pm 7.69$ & 15.75 & 0.06 & $0.39 \pm 0.12$ & 1557 & 20.56 & 0.07 & $0.50 \pm 0.15$ \\
\hline 08 & LS13-09 & 30.1406 & 102.8078 & 11 & $38.60 \pm 3.08$ & 10.29 & 0.05 & $0.18 \pm 0.02$ & 3343 & 8.35 & 0.04 & $0.15 \pm 0.02$ \\
\hline 09 & LS13-14 & 30.4175 & 103.2803 & 11 & $45.79 \pm 5.13$ & 6.90 & 0.04 & $0.10 \pm 0.02$ & 5813 & 6.89 & 0.04 & $0.10 \pm 0.02$ \\
\hline 10 & LS13-20 & 30.1845 & 102.6630 & 10 & $41.18 \pm 3.54$ & 15.16 & 0.06 & $0.24 \pm 0.03$ & 2460 & 12.03 & 0.05 & $0.20 \pm 0.03$ \\
\hline 11 & LS13-21 & 30.0166 & 102.5564 & 8 & $37.96 \pm 7.06$ & 11.75 & 0.05 & $0.21 \pm 0.04$ & 2896 & 10.60 & 0.05 & $0.19 \pm 0.04$ \\
\hline 12 & LS13-22 & 30.4813 & 102.8929 & 10 & $58.19 \pm 8.53$ & 30.07 & 0.09 & $0.34 \pm 0.06$ & 1789 & 24.83 & 0.08 & $0.28 \pm 0.05$ \\
\hline 13 & LS13-23 & 30.2759 & 103.2439 & 13 & $31.89 \pm 2.28$ & 6.53 & 0.03 & $0.14 \pm 0.02$ & 4258 & 6.44 & 0.03 & $0.14 \pm 0.02$ \\
\hline 14 & LS13-24 & 30.5937 & 103.1030 & 11 & $97.25 \pm 30.82$ & 30.67 & 0.09 & $0.20 \pm 0.07$ & 2929 & 24.18 & 0.07 & $0.16 \pm 0.05$ \\
\hline 15 & LS13-28 & 30.9156 & 103.3454 & 13 & $22.26 \pm 2.36$ & 19.37 & 0.06 & $0.57 \pm 0.08$ & 1050 & 21.47 & 0.07 & $0.63 \pm 0.09$ \\
\hline 16 & LS17-05 & 30.0258 & 102.7248 & 28 & $27.12 \pm 1.70$ & 10.29 & 0.04 & $0.26 \pm 0.03$ & 2349 & 10.35 & 0.05 & $0.26 \pm 0.03$ \\
\hline 17 & LS17-06 & 30.0230 & 102.7889 & 29 & $27.92 \pm 1.82$ & 17.74 & 0.06 & $0.42 \pm 0.05$ & 1435 & 17.64 & 0.06 & $0.42 \pm 0.05$ \\
\hline 18 & LS17-07 & 30.3716 & 102.8111 & 25 & $25.15 \pm 3.59$ & 26.81 & 0.08 & $0.69 \pm 0.12$ & 865 & 22.47 & 0.07 & $0.58 \pm 0.10$ \\
\hline 19 & LS17-08 & 30.3141 & 102.7743 & 26 & $22.50 \pm 1.61$ & 13.50 & 0.05 & $0.40 \pm 0.05$ & 1504 & 13.02 & 0.05 & $0.39 \pm 0.05$ \\
\hline 20 & LS18-01 & 29.9913 & 102.4468 & 24 & $39.81 \pm 2.17$ & 16.41 & 0.06 & $0.27 \pm 0.03$ & 2202 & 15.18 & 0.06 & $0.25 \pm 0.03$ \\
\hline 21 & LS18-02 & 30.0160 & 102.4560 & 25 & $35.16 \pm 3.06$ & 25.42 & 0.08 & $0.47 \pm 0.06$ & 1274 & 29.11 & 0.08 & $0.54 \pm 0.07$ \\
\hline 22 & LS18-03 & 30.1007 & 102.7393 & 25 & $34.69 \pm 2.32$ & 17.18 & 0.06 & $0.33 \pm 0.04$ & 1837 & 15.66 & 0.06 & $0.30 \pm 0.04$ \\
\hline 23 & LS18-05 & 30.0438 & 103.0153 & 25 & $49.23 \pm 3.31$ & 7.79 & 0.04 & $0.11 \pm 0.01$ & 5558 & 7.79 & 0.04 & $0.11 \pm 0.01$ \\
\hline 24 & LS18-06 & 30.5849 & 103.2915 & 25 & $38.01 \pm 2.74$ & 11.73 & 0.05 & $0.21 \pm 0.03$ & 2907 & 12.34 & 0.05 & $0.22 \pm 0.03$ \\
\hline
\end{tabular}


a Mass of pure quartz dissolved.

${ }^{\mathrm{b}}$ In situ produced cosmogenic nuclides concentrations based on sample mass and ${ }^{10} \mathrm{Be} /{ }^{9} \mathrm{Be}$ ratios which were performed at the French AMS national facility ASTER (Arnold et al., 2010), normalized to standard reference material 4325 , with a specified ${ }^{10} \mathrm{Be} /{ }^{9} \mathrm{Be}$ ratio of $2.79 \pm 0.03 \times 10^{-11}$ and a ${ }^{10} \mathrm{Be}$ half-life of $1.36 \pm 0.07 \times 10^{6}$ years (Nishiizumi et al., 2007). The analytical uncertainties (reported as $1 \sigma$ ) include a $1.08 \%$ uncertainty on the certified standard ratio, a $1 \sigma$ uncertainty associated with the chemical blank measurement, a $1 \sigma$ statistical error on AMS counting, and a conservative $0.5 \%$ external machine uncertainty. ${ }^{\mathrm{c}}$ Without considering heterogeneities in quartz distribution

${ }^{\mathrm{d}}$ Considering heterogeneities in quartz distribution, weighted at each pixel of DEM by the relative proportion of quartz in the underlying lithology (The estimated proportions of quartz are: Granitoid rocks: 25\%; Sedimentary rocks: 5\%; Carbonate and mafic rocks: $0 \%$ ).

e Spallogenic production rate. Latitude and local altitude correction according to Lal (1991) and Stone (2000), topographic shielding correction according to

Dunne et al. (1999).

${ }^{\mathrm{f}}$ Muogenic production rate. Latitude and local altitude correction according to Lal (1991) and Stone (2000), topographic shielding correction according to Dunne et al. (1999).

$\mathrm{g}$ Denudation rate based on an assumed bedrock density of $2.7 \mathrm{~g} \mathrm{~cm}^{-3}$.

h Timescale of integration for denudation $\left(\mathrm{T}=\mathrm{z}^{*} /\right.$ denudation rate, with $\mathrm{z}^{*}$ the absorption depth scale). 
Figure 1

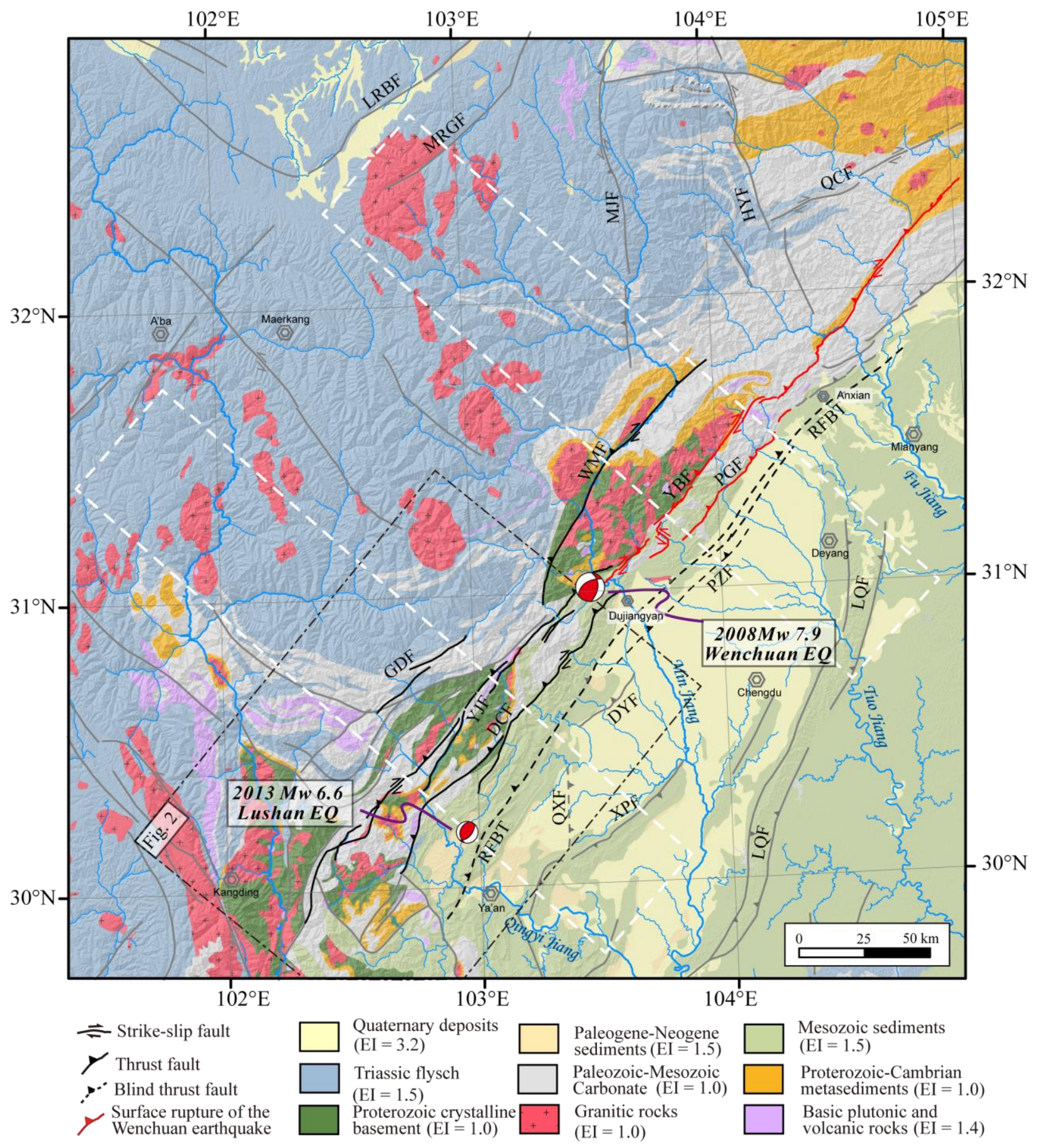


Figure 2

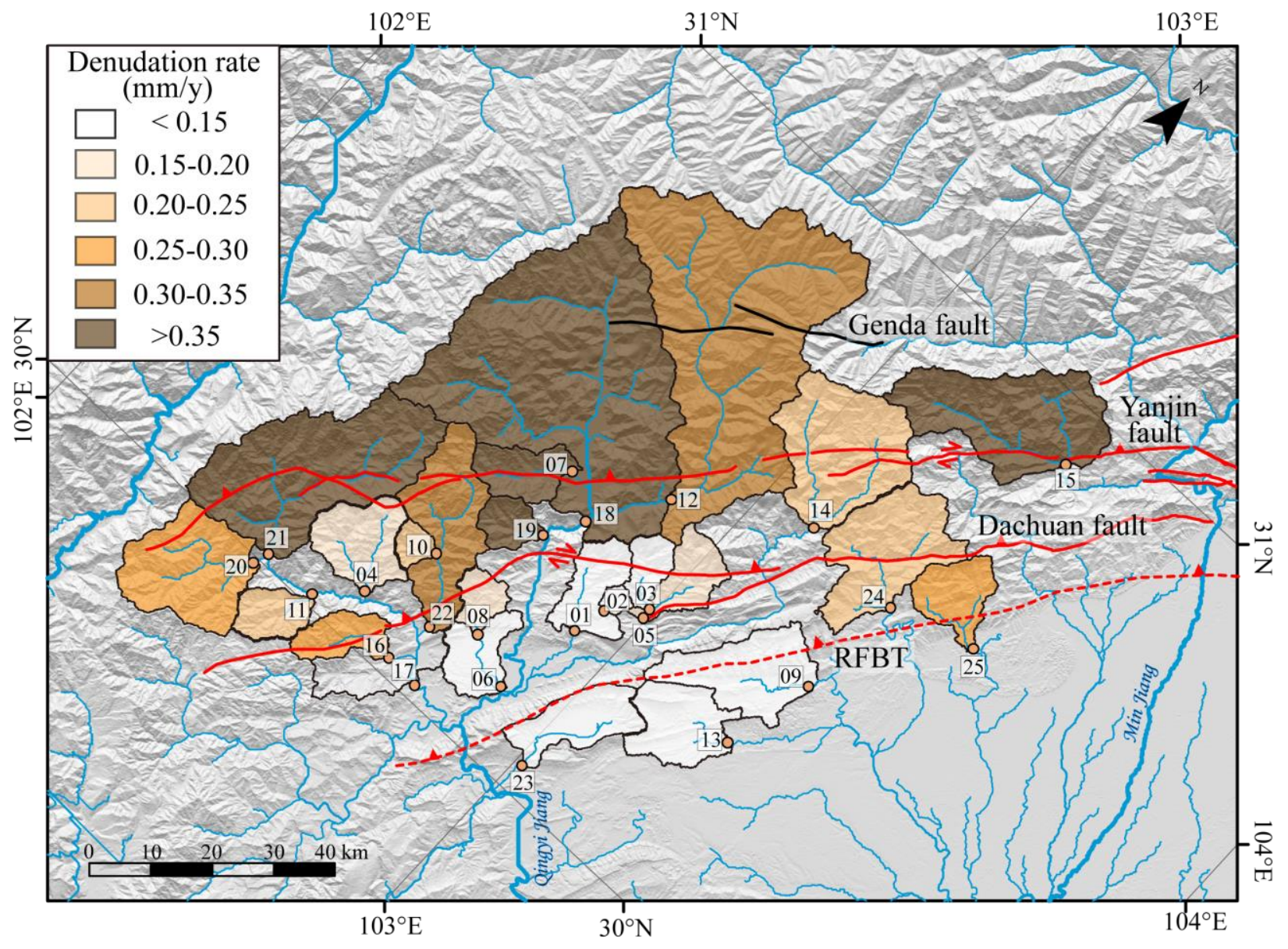


Figure 3
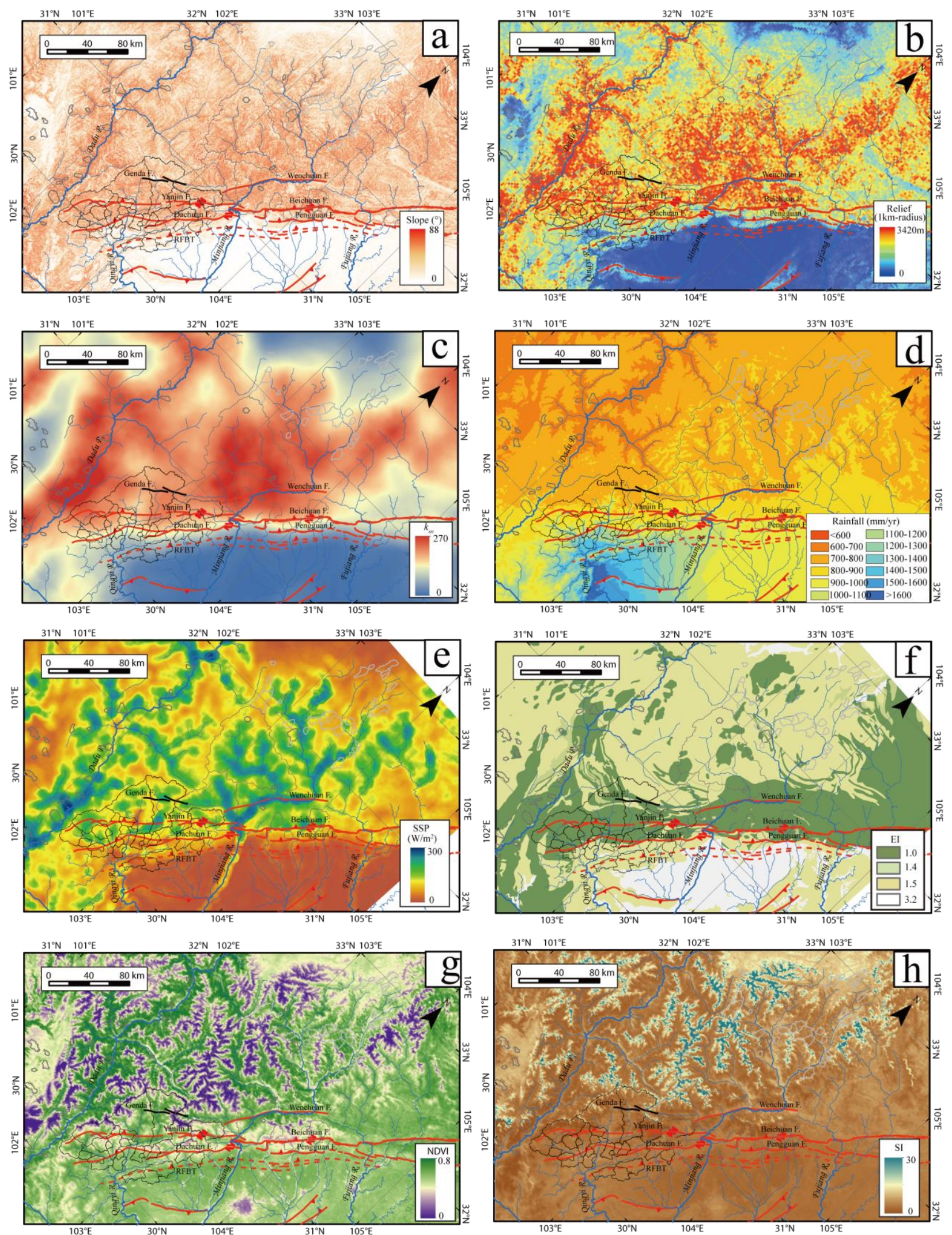
Figure 4
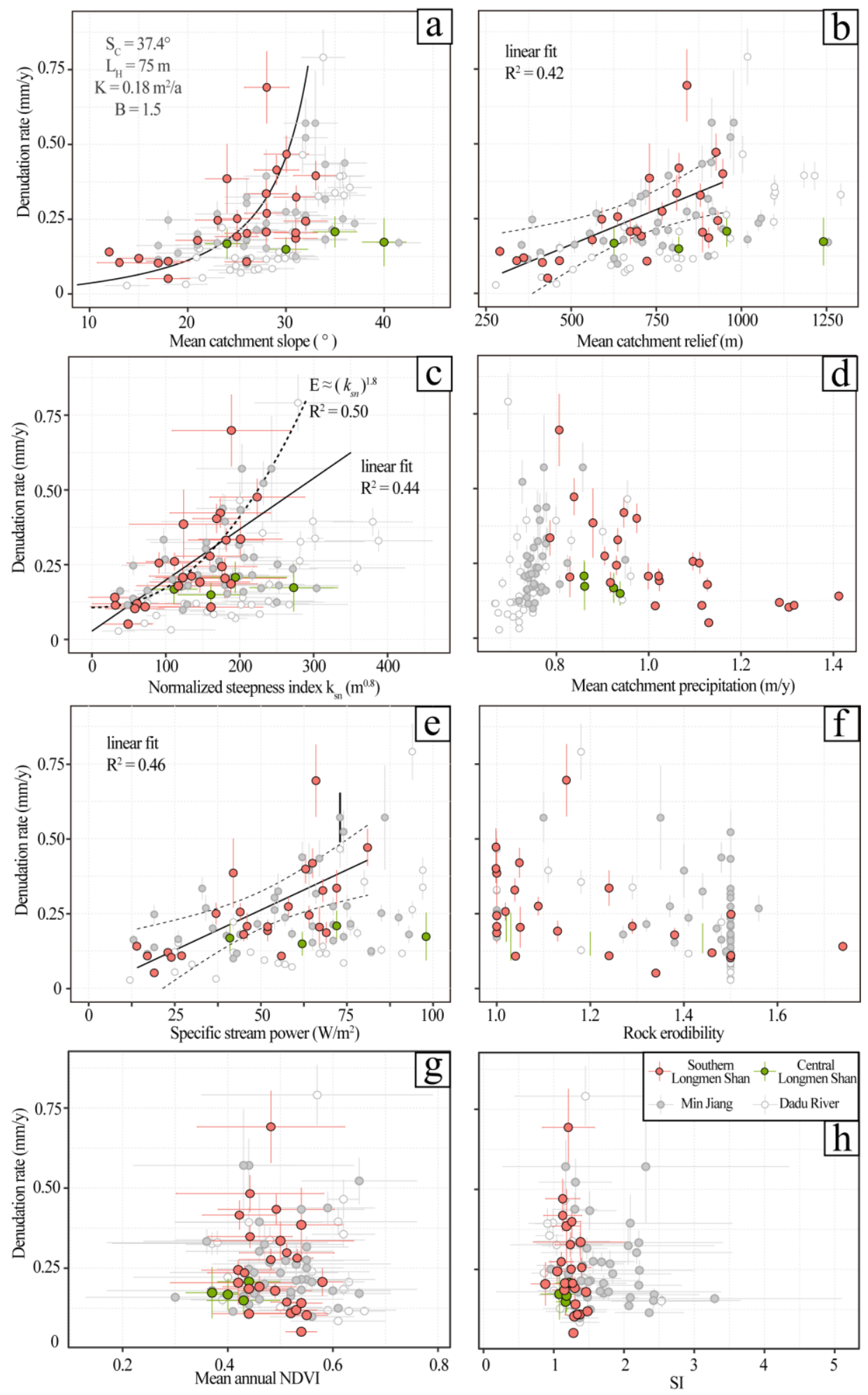
Figure 5

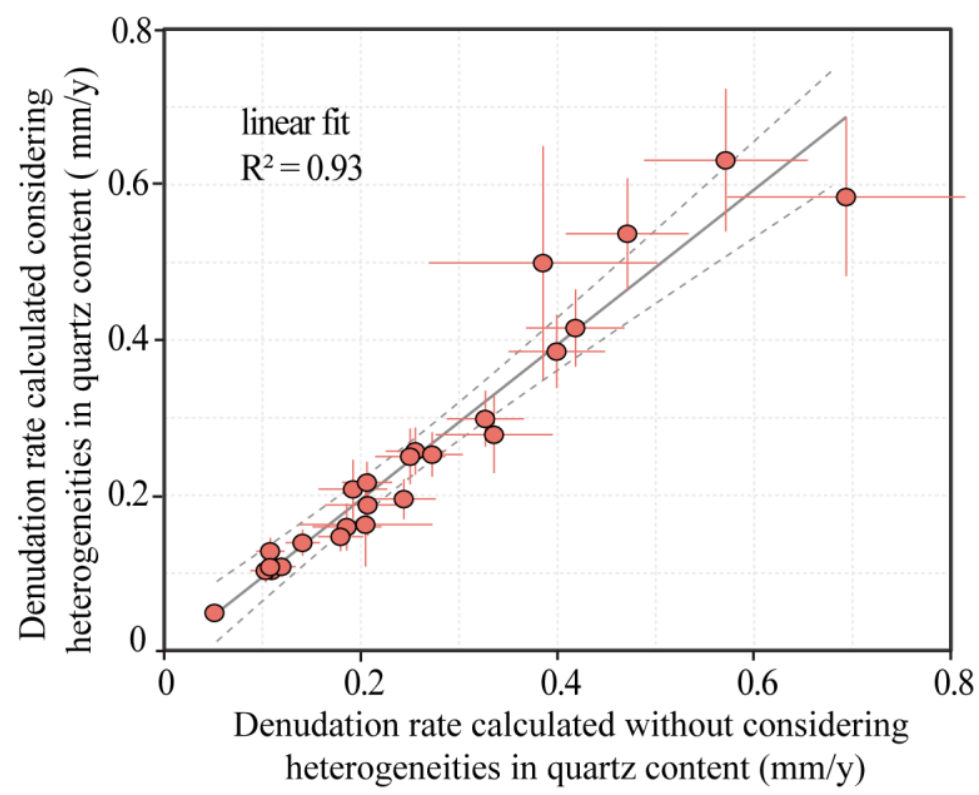


Figure 6
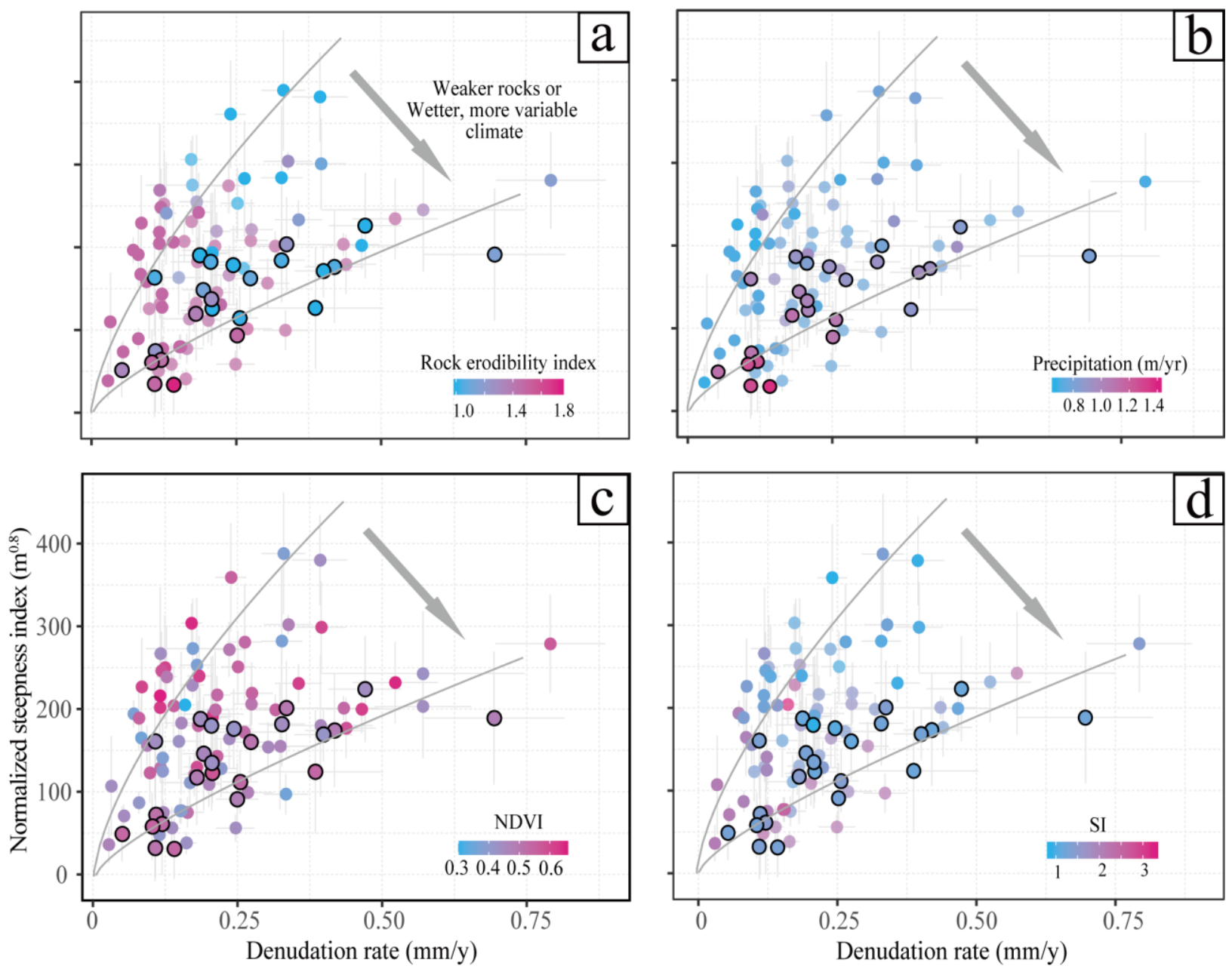
Figure 7
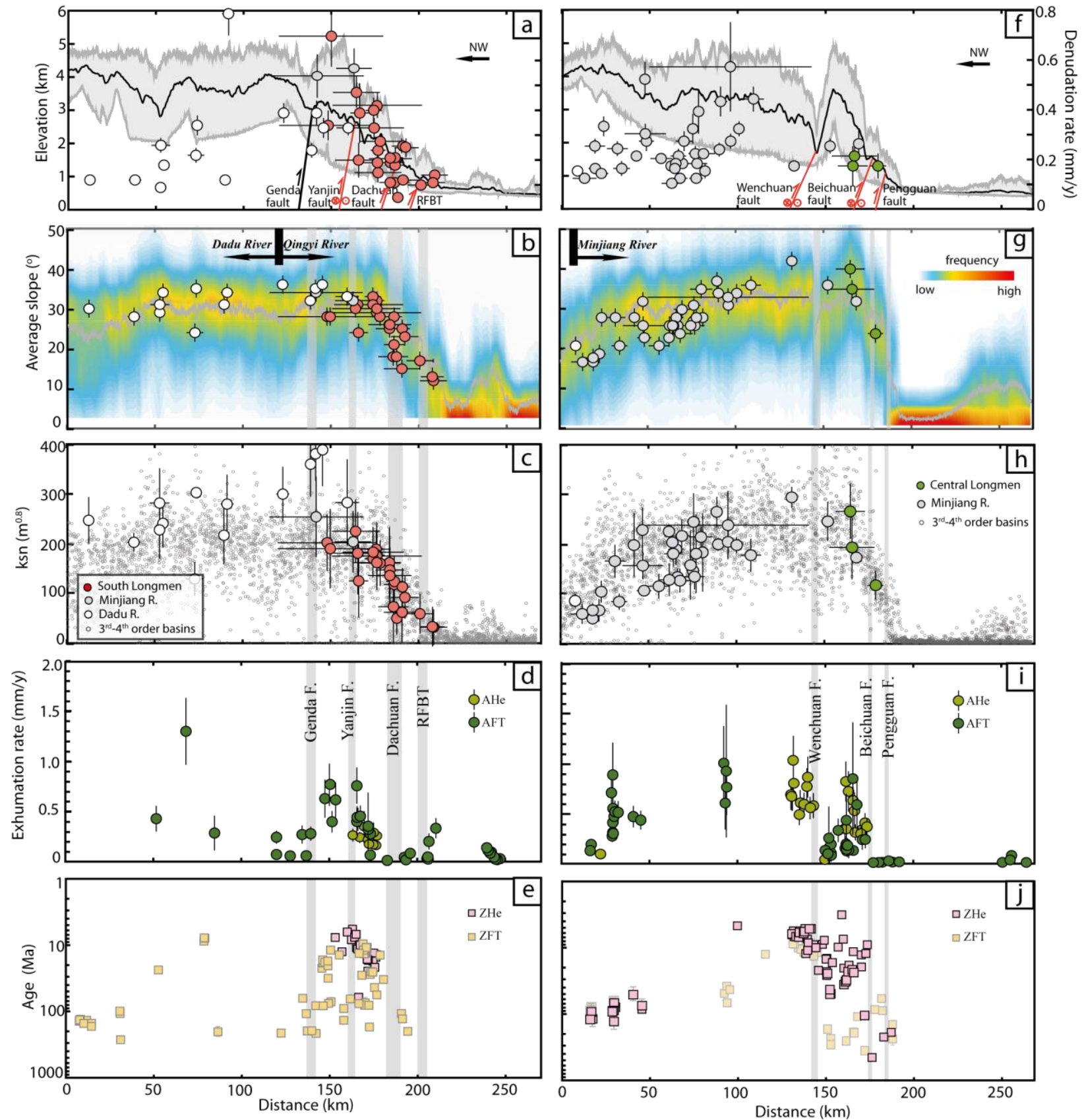
Figure 8

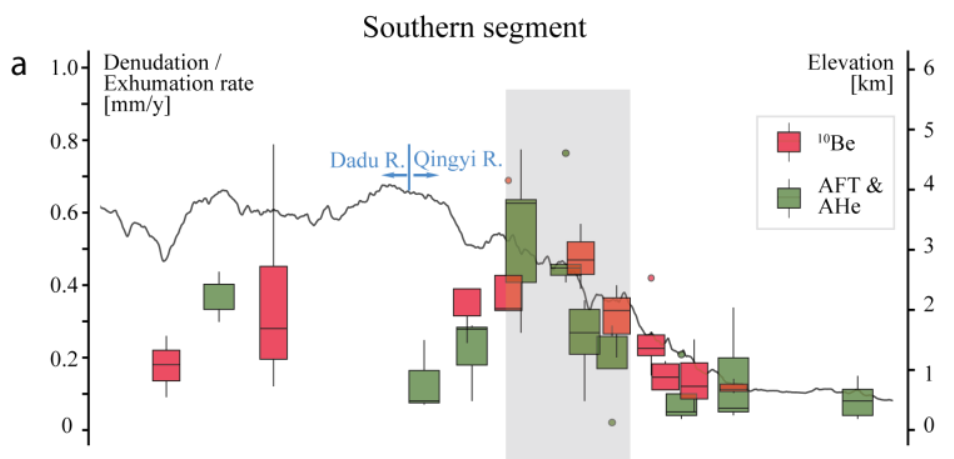

b
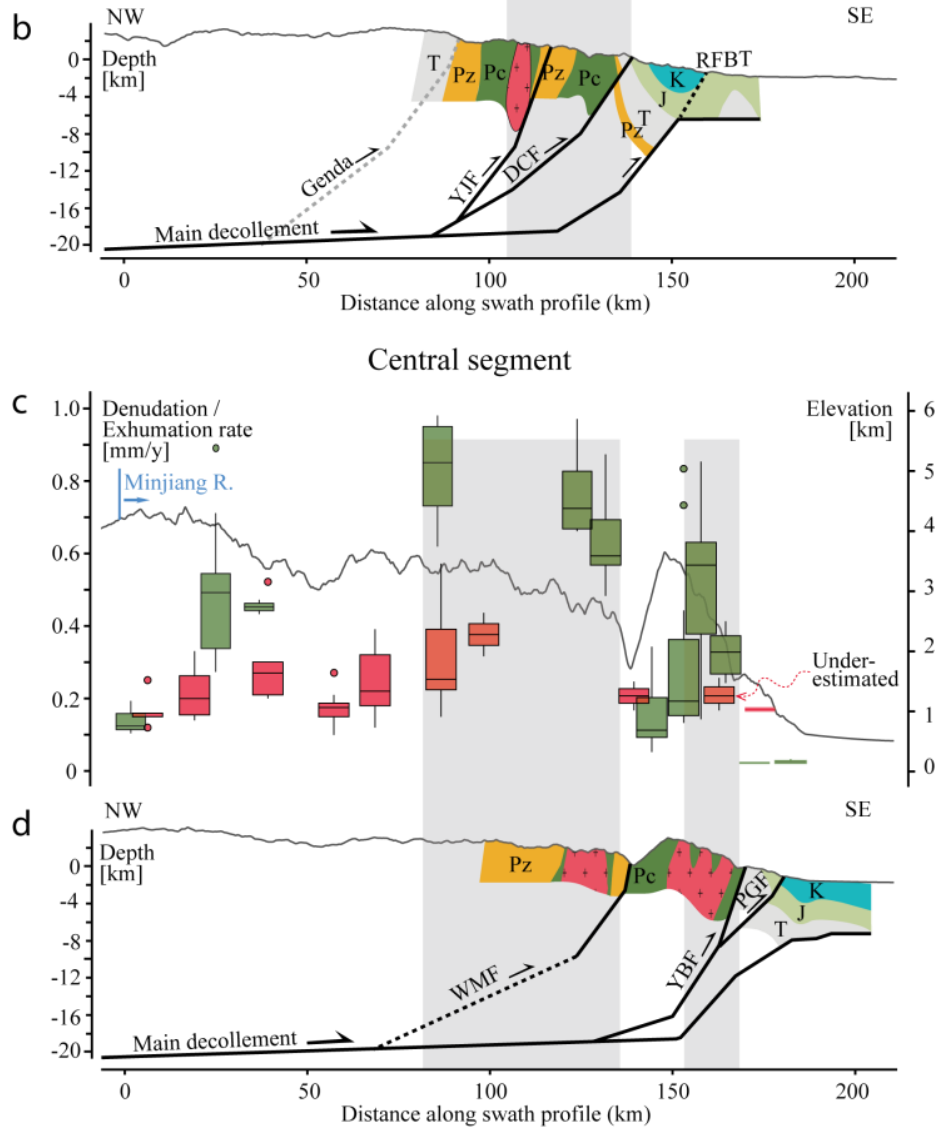